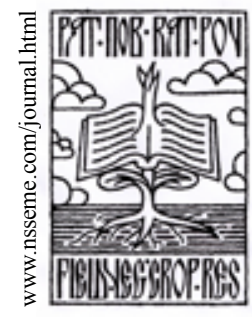

\title{
Significance of Genetic Resources of Cool Season Annual Legumes: I. Crop Wild Relatives
}

\author{
Aleksandar Mikić • Vojislav Mihailović
}

\author{
received: 13 November 2013, accepted: 6 March 2014 \\ published online: 2 June 2014 \\ (C) 2014 IFVC \\ doi:10.5937/ratpov51-4896
}

\begin{abstract}
Summary: This review is attempting to present the wild relatives of cool season annual legumes and thus hopefully answer to how and what these taxa, colloquially said, have to offer to the cultivated crops, in terms of yield, quality, stress resistance and other economically important issues. They represent a wide gene pool of various desirable traits, especially those related to abiotic and biotic stress resistance that may be introgressed into the advanced cultivars, with overcoming potential physiological or genetic barriers. The wide mutual variations of the most important characteristics may be extremely beneficial for the advanced cultivars due to numerous bottlenecks and their narrow genetic base. If considered from a wider point of view, wild relatives of cool season annual legumes represent not only a national or regional treasury, but also a tool to improve the modern agriculture to the benefit of the whole mankind.
\end{abstract}

Key words: breeding, cool season annual legumes, crop improvement, crop wild relatives, Fabaceae, genetic resources

\section{Introduction}

What is a wild plant species and what is a cultivated crop? In other words, can we tell where and when the former becomes the latter? What is the exact borderline between these two? These are the questions that every botanist, geneticists, breeder or anyone dealing with plants may sometimes and sincerely ask himself. We often speak about domestication and consider it a selection of a plant species from wild flora and a beginning of growing it for specific purposes, most often related to food and other needs of some specific human population. In addition, we tend to regard domestication as a one-way process, that is, if one wild plant species is domesticated, it will remain a cultivated crop forever. However, it has not been so in numerous cases throughout the history of mankind. In some of them, the cultivation of one wild plant species was attempted and due to various reasons completely and definitely abandoned. In the others, diverse reasons made the populations of certain cultivated crops returned to wild flora

A. Mikić* $\bullet$ V. Mihailović

Institute of Field and Vegetable Crops, Maksima Gorkog 30, 21000

Novi Sad, Serbia

e-mail: aleksandar.mikic@ifvcns.ns.ac.rs and remained there until today. A fine example for the first case is reflected through the results of an archaeobotanical analysis of the remains of the hundreds of charred seeds of rambling vetch (Vicia peregrina L.) from the site of Netiv Hagdud, at the lower Jordan valley and dated to 11,300-10,900 years BP (Melamed et al. 2008). They show that the seeds might have been collected from wild flora or harvested together with barley (Hordeum vulgare L.) from the tilled fields. However, all these efforts were merely a trial of domestication, ending with a final abandonment, probably due to a prominent toxicity of the seeds and undesirable taste. A curious report for the second case comes from southeast Serbia. There, probably the first known analysis of a legume ancient DNA of the charred common pea (Pisum sativum L.) and bitter vetch (Vicia ervilia (L.) Willd.) from the fortified settlement of Hissar, dated to about 1,200 years

\footnotetext{
Acknowledgements:

The Project TR-31024 financed by the Ministry of Education, Science and Technological Development of the Republic of Serbia.

The authors would like to thank most sincerely to Mike Ambrose, Svetlana Antanasović, Branko Ćupina, Catherine Delaitre, Gérard Duc, Vuk Đorđević, Živko Jovanović, Aleksandar Medović, Petr Smýkal, Margarita Vishnyakova, Bojan Zlatković and Lana Zorić for their support and encouragement.
} 
BCE, showed that it was rather closely related to a modern population of 'tall' pea (Pisum sativum L. subsp. elatius (Steven ex M. Bieb.) Asch. \& Graebn.) Alef.) from some hundred kilometres southwards (Medović et al. 2010, Jovanović et al. 2011). We may only speculate if the people from Hissar, then the northernmost point of a Hellenic civilisation, cultivated 'tall' pea and that it, after Hissar had been abandoned, destroyed or deserted by some war, peaceful migration or epidemic disease, returned to wild flora, spreading in all directions, or if they collected it from its natural habitats in woodland margins and used together with common pea.

Legumes (Fabaceae Lindl., syn. Leguminosae Juss. and Papilionaceae Giseke) are one of the plant families with the largest number of economically important crops. They comprise some of the most ancient and first domesticated species such as common chickpea (Cicer arietinum L.), common lentil (Lens culinaris Medik.), pea and bitter vetch (Zohary \& Hopf 2000), as witnessed by numerous archaeobotanical (Tanno \& Willcox 2006) and palaeolingustic analyses (Mikić 2012) analysis. It is breeding that causes the bottlenecks that target yield and quality. By this reason, it is essential to find solutions for narrowing the genetic basis of legume crops. One of the ways to answer this in a sustainable and feasible way may be to use crop wild relatives that represent a gene pool of numerous desirable traits of economic importance by introgression into the cultivated crops (Maxted et al. 2006).

This review is attempting to present the wild relatives of cool season annual legumes and hopefully answer to how and what these taxa, colloquially said, have to offer to the cultivated crops, in terms of yield, quality, stress resistance and other economically important issues.

\section{Yellow vetchling (Lathyrus aphaca L.)}

Yellow vetchling is an annual legume species that is a regular member of many European and Mediterranean wild floras (Boža et al. 2003) and almost always considered a weedy legume species. A complex research carried out at several sites from Epipalaeolithic and Mesolithic in southern France revealed a material evidence of yellow vetchling in the form of charred seeds, probably as an accompanying weed of the cultivated grain legumes such as common chickpea, common lentil and common pea (Vaquer et al. 1986). The research on the impact yellow vetchling regarded as a weed may have on diverse ecosystems has a long tradition (Singh \& Singh 1939). It is one of the broadleaved weeds capable of removing nitrogen, phosphorus, potassium and other essential nutrients from cultivated crops and thus cause a certain decrease of yield, such as shown by a trial with common wheat (Triticum aestivum L.) in Uttar Pradesh, India (Johri et al. 1992). On the other hand, if regarded as an arable weed, yellow vetchling may be an indicator organism of biodiversity in agroecosystems and assist in evaluating species for conservation effects of various management practices (Albrecht 2003).

In a cytogenetical sense, for both molecular taxonomy and potential applied research, it is important that yellow vetchling, like most of its closest botanical relatives, has $2 n=14$ chromosomes (Sahin et al. 2000). One of the most prominent morphological characteristics of yellow vetchling is its leaf structure, consisting solely of large stipules and tendrils. A physiological testing carried out on several populations of yellow vetchling showed that its stipules in all tissue aspects were quite similar to those of leaflets in other Lathurus species and other close botanical relatives, as well as that they were responsible for more than $95 \%$ of the yellow vetchling photosynthesis (Sharma \& Kumar 2012). This knowledge may have positive implications on the physiological research and breeding of the semi-leafless genotypes of common pea, also with stipules and tendrils only and no leaflets.

One of the main obstacles in attempting to transform yellow vetchling from a wild or weedy species into a cultivated crop could be prominent seed dormancy (Van Assche \& Vandelook 2010), well present among many legume crop wild relatives and requiring an additional effort in their pre-breeding. However, despite this, yellow vetchling is grown and used for diverse purposes in the world. In milder climates, with relatively cool winters and very hot summers, such as in Hisar in India, there is just one growing season of yellow vetchling, with sowing in early November. This provides the most desirable relationship among its grain yield components and the highest seed yield (Balyan et al. 1991). In Pakistan, yellow vetchling is one of the commonly grain legumes used as poultry feed along with guar (Cyamopsis tetragonoloba (L.) Taub.) (Khan 1994). In a study of seed phenolics, the seeds of yellow vetchling were twice richer in phenolics and possessed the highest relative antioxidant activity in comparison to those in chickpea, lupins (Lupinus spp.) and soybean (Glycine $\max$ (L.) Merr.) (Pastor-Cavada et al. 2009a), thus providing wild Lathyrus species with an additional value for cultivation.

A series of trials was carried out at Rimski Šančevi in northern Serbia assessing the possibility 
Table 1. Average values of forage yields in wild populations of yellow vetchling for the years of 2010 and 2011 at Rimski Šančevi (Mikić et al. 2012b)

\begin{tabular}{lll}
\hline Population & $\begin{array}{l}\text { Fresh forage yield } \\
\left(\mathrm{t} \mathrm{ha} \mathrm{a}^{-}\right)\end{array}$ & $\begin{array}{l}\text { Forage dry matter yield } \\
\left(\mathrm{t} \mathrm{ha} \mathrm{a}^{-1}\right.\end{array}$ \\
\hline LA 01 & 16.1 & 3.1 \\
LA 02 & 11.4 & 2.3 \\
LA 03 & 11.6 & 2.2 \\
LA 04 & 14.2 & 2.7 \\
LA 05 & 10.6 & 2.0 \\
LA 06 & 10.0 & 2.0 \\
Mean & 12.3 & 2.4 \\
$L S D_{0.05}$ & 5.01 & 1.11 \\
\hline
\end{tabular}

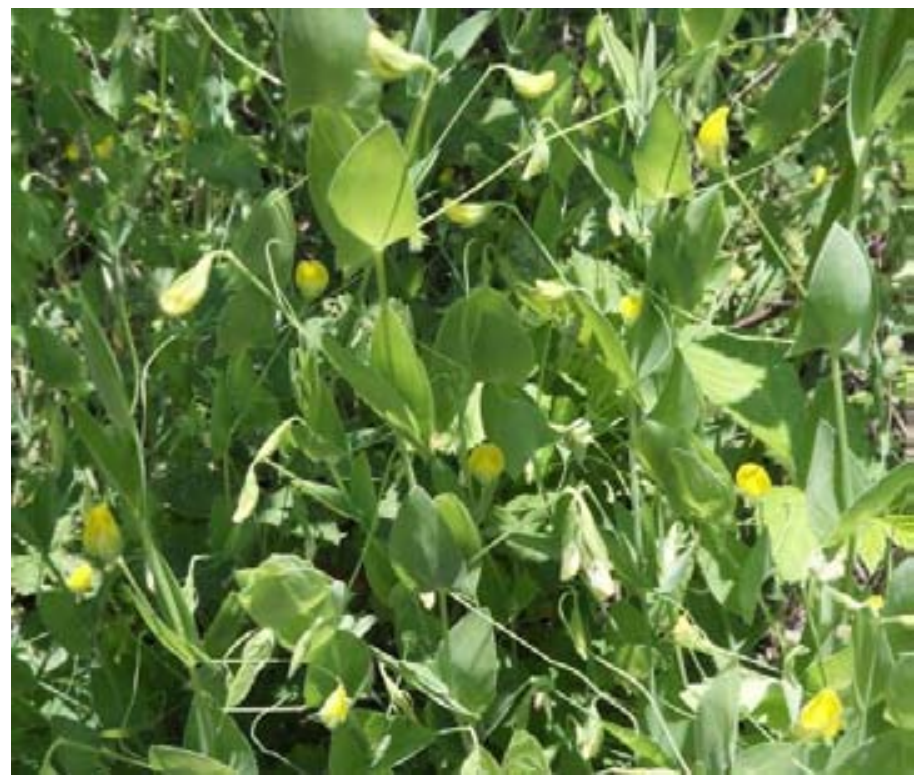

Figure 1. A population of yellow vetchling on the slopes of the mountain Starac in southeast Serbia in May 2011 (Photo: Petr Smýkal)

of growing yellow vetchling for forage production (Mikić et al. 2012b). With an average two-year forage dry matter yield of $2.4 \mathrm{tha}^{-1}$, yellow vetchling proved to be significantly less productive than annual forage legumes, such as common pea and common vetch (Vicia sativa L.) (Table 1). However, a significant short period to full flowering, as an optimum stage for cutting (Figure 1), in all springtested yellow vetchling populations of about 60 days, enables its use as an early-spring crop after which maize (Zea mays L.), sunflower (Helianthus annuus L.) and other mid- or late spring-crops may be regularly sown. Also, yellow vetchling may be intercropped with other 'short' spring-sown cool season annual legumes, where it would play a role of supported crop, while semi-leafless common pea would be a supporting crop (Mikić et al. 2012a).

In general, the studies on the relationship between yellow vetchling and the microorganisms have not been as numerous as in other Lathyrus species or economically important annual legumes. In a study comprising 50 legume species assessed for association of Vesicular-Arbuscular Mycorrhizal fungi, it was found that in the case of the wild populations of yellow vetchling it was absent (Bargali 2011). A series of field trials in southern Spain, where crenate broomrape (Orobanche crenata Forssk.), a parasite weed, causes significant 
troubles in the production of many grain legumes, it was found that the wild populations of yellow vetchling were moderately to highly susceptible, with more than $34 \%$ emerged broomrape shoots (Sillero et al. 2005a).

\section{Black lentil (Lens nigricans (M. Bieb.) Godr.}

Black lentil is one of the wild relatives of common lentil and, in a taxonomical sense, is further from then the other members of common lentil, such as L. culinaris subsp. odemensis (Ladiz.) M. E. Ferguson et al. or L. culinaris subps. orientalis (Boiss.) Ponert, as confirmed by a study on their phylogenetic relationship by isozyme loci (de la Rosa \& Jouve 1992). Together with other Lens species, it is present in the archaeolobotanical material in central and western Asia, suggesting this region may be a geographic centre of the domestication of common lentil (Vaquer 1986). The archaeological findings in Near East also contain the charred remains of black lentil, supporting a theory that the domestication of legumes could predate the domestication of that of cereals (Kislev \& Bar-Yosef 1988).

Wild populations of black lentil are often found extremely localised in abandoned human habitats (Ferguson \& Robertson 1999) and may have a potential use in the improvement of common lentil. It is certain that the ecology factors strongly affect the wild populations and that the intrapopulation diversity of the wild populations of black lentil is wide. Crossing black lentil with common lentil often fails because of diverse forms of mutual incompatibility. Being the most distant species within the genus Lens, black lentil proved to be without any success of a true domestication
(Sonnante et al. 2009). However, numerous physiological and genetic tools are available for the inter-species hybrid embryo rescue, with emphasis of removing non-desirable traits, such as seed dormancy (Ladizinsky \& Muehlbauer 1993).

Establishing the collections of the populations from wild flora (Figure 2) may assist in assessing its economically important traits. The results of an analysis of the fatty acid composition of the oil in the grain of the wild populations, including black lentil, and local landraces of several annual legumes, showed that all studied species had higher amount of total unsaturated fatty acids. The wild populations of black lentil were the most abundant in the content of palmitic acid (19.3\%) and with a low $\omega 6 / \omega 3$ ratio of $2.0 \%$ (Pastor-Cavada $2009 \mathrm{~b}$ ). An analysis of the Bowman-Birk inhibitors in common lentil demonstrated that at least two paralog genes controlled their genetic structure, as well as that all other Lens species had ortholog genes for this important grain quality trait. The tested wild populations of black lentil had the most divergent sequences at the nucleotide and the amino acid level (Sonnante et al. 2005).

Black lentil has the maximum resistance to various forms of abiotic and biotic stress (Gupta \& Sharma 2006). In North Africa and West Asia, wild populations of black lentil demonstrated a high tolerance to drought, although its production for forage is rather uncertain, thus requiring introgression of desirable traits from black lentil to common lentil (Hamdi \& Erskine 1996). Ascochyta blight, induced by Ascochyta fabae f. sp. Lentis Gossen, Sheard, C.J. Beauch. \& Morrall, is a major foliar disease affecting lentil (Bayaa et al. 1994). The resistance of wild populations of black lentil to achochyta blight is controlled by two

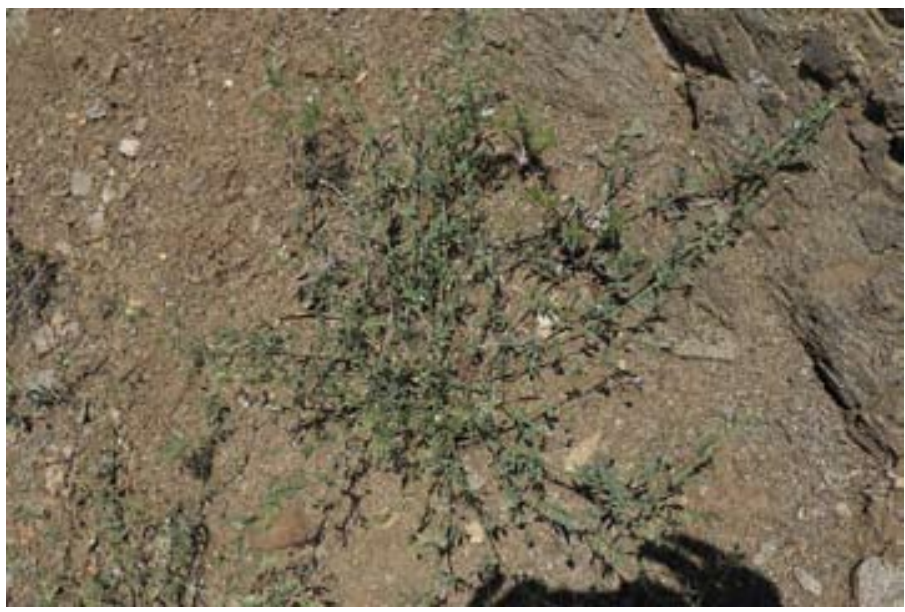

Figure 2. A wild population of black lentil on the slopes of the mountain Starac in southeast Serbia in May 2011 (Photo: Petr Smýkal) 
complementary genes. Both genes must be in a dominant state, because otherwise one gene will be masked by another and the genotype will be susceptible to the disease. It is recommended that the interspecific hybridisation with common lentil may introgress this important trait into the latter (Ahmad et al. 1997). In a trial carried out in parallel in the agroecological conditions of Germany and North America, wild populations of black lentil proved to be more resistant to the anthracnose (Colletotrichum truncatum (Schwein.) Andrus et W.D. Moore) race $\mathrm{Ct} 0$ in comparison to other Lens cultivars (Tullu 2006). Large proportions of grain yield are lost due to diverse forms of biotic stress in the Mediterraneaan countries (El-Bouhssini et al. 2008). One of them is Sitona weevil (Sitona crinitus Herbst), a major pests limiting lentil production mostly in the countries of West Asia and North Africa. Together with other wild Lens species, black lentil may be a source of the resistance of this genus for weevil in common lentil (Fratini \& Ruiz 2006).

\section{Red-yellow pea (Pisum fulvum Sm.)}

The status of red-yellow pea as a separate species within the genus Pisum has always been considered certain by many botanical classifications and recently was confirmed by numerous molecular analyses (Smykal et al. 2010). Red-yellow pea has the same number of chromosomes as common pea, $2 n=14$ (Lifante et al. 1992), with certain differences in the karyotype, such as relative arm length of the chromosomes and an additional satellite in one of them (Errico et al. 1991). Redyellow pea is native to Armenia, Cyprus, Greece, Iraq, Israel, Jordan, Lebanon, Syria and Turkey (Maxted \& Ambrose 2001). In Near East, it usually grows in the woodlands or forest margins. It is generally regarded that red-yellow pea has remained fully wild species, retaining typical characteristics such as dehiscent pods, smaller seeds and thick seed coat (Weeden et al. 2002). On the other hand, an archaeobotanical analysis of the plant remains found in Kebara cave, Israel, from Middle Palaeolithic, revealed that red-yellow pea could be a small part of the everyday human diets along with other grain legumes (Lev et al. 2005). The same practice of collecting the grains of the wild populations of red-yellow pea is still present to a small extent among rural farmers, Bedouine shepherds and semi-urban people (Al-Qura'n 2010).

Developing interspecific hybrids between the wild populations of red-yellow pea and common pea was proved to be possible. An experience from Australia suggests that breeding commercial common pea to the some disease should be done in two steps, with the first one being maximising field resistance through isolation of the best crossing combinations of wild genotypes of common pea as a bridging cross and the second step being improving the agronomic performance by backcrosses with advanced cultivars (Wroth 1998). Later, as strongly suggested by flow cytometry and isoenzymes with leaf tissues, there proved to be no need to use more wild types of common pea, such as 'tall' pea or field pea (P. sativum L. subsp. sativum var. arvense (L.) Poir.), as a bridging cross for the hybridisation with the wild populations of red-yellow pea (Ochatt et al. 2004). On the other hand, many interspecific crossing combinations between the wild populations of red-yellow pea and common pea may be unsuccessful due to an incompatibility related to cytoplasm factors (Bogdanova \& Kosterin 2007). Another difference between the wild populations of red-yellow pea and common pea, responsible for a potential lack of success in the interspecific crossing, is that the former has a fast variant of the nuclear encoded seed albumin $\left(\mathrm{SCA}^{\mathrm{F}}\right)$ and the presence of both the plastid gene $r b c L$ and the mitochondrial gene cox 1 (Kosterin \& Bogdanova 2008).

Crossing between the wild populations of redyellow pea and the advanced cultivars of common pea is of a particular interest in applied research, such as breeding (Figure 3). A study on the grain yield components of the wild populations of red-yellow pea is essentially important for their crossing with common pea and a possible prediction of the grain yield components in their hybrid progenies. In a field trial carried out in Novi Sad, northern Serbia, it was shown that grain yield per plant in the wild populations of red-yellow pea was highly positively correlated with number of fertile nodes, number of pods per plant and number of grains per plant (Table 2) (Mikić et al. 2013b). On the other hand, the action of the flowering allele $H r$, responsible for basal branching, may make developing hybrid progenies between the wild populations of redyellow pea and common pea rather complicated by inducing a great length of the stems, poor lodging resistance and a high content of trypsin inhibitors in the grain (Smýkal et al. 2012).

In a field trial comprising various Pisum taxa carried out in Norwich, UK, the wild populations of red-yellow pea showed a strong resistance to powdery mildew, one of the economically most important diseases in the cultivated pea (Ambrose 2009). Several other analyses discovered that the resistance to powdery mildew in the wild 


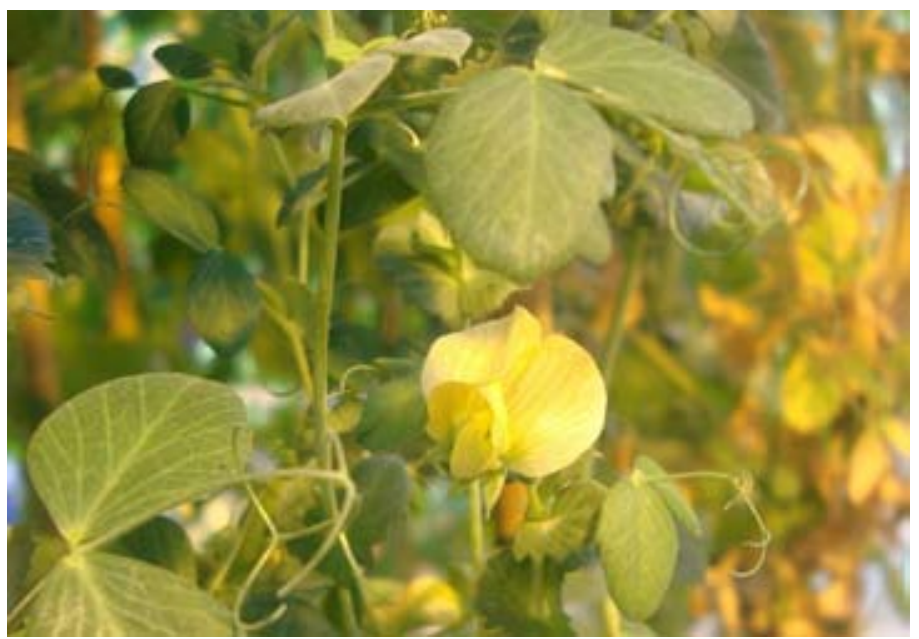

Figure 3. A flower of red-yellow pea in a glasshouse test at INRA, Dijon, France, in 2011 (Photo: Svetlana Antanasović)

Table 2. Simple correlation coefficients $(r)$ among the seed yield components and seed and straw yields in red-yellow pea accessions (Mikić et al. 2013b)

\begin{tabular}{|c|c|c|c|c|c|c|c|c|}
\hline & 2 & 3 & 4 & 5 & 6 & 7 & 8 & 9 \\
\hline 1 & -0.075 & 0.615 & 0.082 & 0.140 & 0.272 & 0.113 & 0.324 & 0.230 \\
\hline 2 & & 0.118 & -0.102 & -0.219 & -0.183 & -0.575 & -0.427 & $0.846^{* *}$ \\
\hline 3 & & & 0.021 & 0.044 & 0.255 & -0.097 & 0.205 & 0.283 \\
\hline 4 & & & & $0.969^{* *}$ & $0.735^{*}$ & 0.373 & $0.820^{* *}$ & -0.161 \\
\hline 5 & & & & & $0.741^{*}$ & 0.409 & $0.839^{* *}$ & -0.280 \\
\hline 6 & & & & & & 0.080 & $0.881^{* *}$ & -0.277 \\
\hline 7 & & & & & & & 0.523 & -0.269 \\
\hline 8 & & & & & & & & -0.346 \\
\hline
\end{tabular}

(1) Main stem length (cm); (2) Number of stems plant ${ }^{-1}$; (3) Number of total nodes plant ${ }^{-1}$; (4) Number of fertile nodes plant ${ }^{-1}$; (5) Number of pods plant ${ }^{-1}$; (6) Number of seeds plant ${ }^{-1}$; (7) Thousand seeds weight (g); (8) Seed yield $\left(\mathrm{g}\right.$ plant $\left.\mathrm{t}^{-1}\right) ;(9)$ Straw yield $\left(\mathrm{g} \text { plant }{ }^{-1}\right)^{*}$ - significant at 0.05 ; $^{* *}$ - significant at 0.01

populations of red-yellow pea might be controlled either by a new allele of the attested genes $e r l$ and er2, present in the cultivated P. sativum (Fondevilla et al. 2007a). However, the segregation ratios revealed that it is a novel gene, designed as er3 (Fondevilla et al. 2011). The resistance to powdery mildew in the wild populations of red-yellow pea are mostly due to a high frequency of cell death resulting from the response to infection and delayed response after establishing colony (Fondevilla et al. 2007b). A study on the resistance of the wild populations of red-yellow pea with intraspecific crossings identified a quantitative trait locus (QTL) responsible for their resistance to pea rust (Uromyces pisi (Pers.) Wint.) (Barilli et al. 2010).
It was also demonstrated that the wild populations of red-yellow pea are resistant to Mycosphaerella pinodes (Berk. \& A. Bloxam) Vestergr. (Fondevilla et al. 2005).

Until recently, little was known on the possible sources of the resistance to pea weevil (Bruchus pisorum L.), an economically most important pest in common pea in the world (Clement et al. 2009), especially in arid climates. Since they were not found among the taxa of the common pea complex, they were searched for in the wild populations of red-yellow pea. One glasshouse test showed that the wild populations of red-yellow pea, unlike a common pea cultivar serving as a control, had higher mortality of first larvae on pods, higher 
mortality of the weevil stages within seed, lower adult emergence from seed and the smaller seed damage levels (Clement et al. 2002). A technique for screening the wild populations of red-yellow pea showed that its flat and swollen pods are the best substrates for manually transferring pea weevil eggs to intact pods (Hardie \& Clement 2001). A segregation of the hybrid progenies between a wild population of red-yellow pea and common pea in the $F_{2}$ population showed a trigenic mode of inheritance, with additive effects and dominant epistasis and a ratio of $63: 1$, clearly supporting an inheritance controlled by three genes. The full resistance to pea weevil is present if all three genes, designed as PWR $1, P W R 2$ and $P W R 3$, are recessive (Byrne et al. 2008). It is noteworthy that the immature pods of the wild populations of redyellow pea have conspicuous red spots along their pods, appearing to mimic lepidopterian caterpillars and serving as herbivore repellents and parts of the defence systems of the plants of red-yellow pea (Lev-Yadun \& Inbar 2002). A resistance of the wild populations of red-yellow pea to crenate broomrape is also detected (Pérez-de-Luque et al. 2005).

\section{'Tall' pea}

'Tall' pea has been regarded as a separate species within the genus Pisum throughout centuries, but today it is considered another subspecies within the common pea complex (Maxted \& Ambrose 2001). There are reports that, apart from typical pink flowers, there is a variety or form of 'tall' pea named albiflorum, with whole corolla white and found sporadically in the southern Balkan Peninsula (Zlatković et al. 2010). A few specimens of 'tall' pea with the seed coat intact were found in the archaeological findings from early Holocene in Near East (Willcox et al. 2008), confirming that it is a wild progenitor of common pea that took a significant part in spreading the Neolithic plant economies to Europe, North Africa and Central Asia (Coward et al. 2008).

One of the changes that happened during the domestication and evolution of 'tall' pea into the cultivated common pea is the transformation of the seed coat from impermeable in the former to permeable in the latter (Werker et al. 1979). Another obstacle in the domestication of 'tall' pea is seed dormancy or seed hardiness, causing a rather low germination rate and an uncertain production. A trial in Israel showed that scarifying the 'tall' pea seeds resulted in net grain yield gain (Abbo et al. 2011). The productivity of 'tall' pea wild populations seems not to be a key factor in its domestication (Abbo et al. 2008), pointing out that other parameters, such as taste, could be more important. Like many other wild legumes, 'tall' pea is characterised by the pods twisting when they are ripe and thus is able to catapult its seeds about $3 \mathrm{~m}$ from its plant (Ambrose \& Ellis 2008), quickly dispersing to new areas throughout the years. A very important fact for breeders is that, if crossing the wild populations of 'tall' pea with the cultivated common pea, there may appear a nuclear-cytoplasmic sterility, especially if 'tall' pea is the female parent (Bogdanova et al. 2009).

Today, the wild populations of 'tall' pea are becoming more and more extinct, mostly due to the spread of agricultural land and the urban areas. Most of the wild populations of 'tall' pea disappeared during the 20th century. The examples for this sad fact may be found throughout the Europe. Recently, some efforts have been made towards the preservation and conservation of the wild populations of 'tall' pea. In Bulgaria, they were detected in isolated regions, such as the eastern parts of the Rhodope Mountains, south Black Sea region and northern Bulgaria (Mikić et al. 2009a). In Serbia, there are very recent reports that, after nearly a century, the wild populations of 'tall' pea have been found in the southeast part of the country (Zlatković et al. 2010). These populations are not so easily accessible, being rather distant from regularly tilled land and unlike the local landraces of field pea and obviously preferring rocky and grassy slopes, forest and field margins, scrub and ruins, with an altitude of between 0 $\mathrm{m}$ and $1700 \mathrm{~m}$. The new 'tall' pea population (Figure 4) is temporarily protected from the risk of loss by grazing or some other similar danger related to the activity of man.

The collected wild populations of 'tall' pea are characterised for the various anatomical and morphological traits and evaluated for the most significant agronomic characteristics. This may be very useful for breeding purposes by introgressing the desirable traits from the wild populations of 'tall' pea into cultivated common pea, as well as for assessing the potential of their potential for forage and grain production. In a field trial with $e x$ situ evaluation of the wild population of 'tall' pea collected on the slopes of the mountain Kozjak in the upper flow of the river Pčinja in southeast Serbia, carried out in the location in the northern Balkan Peninsula (Ćupina et al. 2011), it was demonstrated that it had a considerable potential for both forage and grain production with a good 


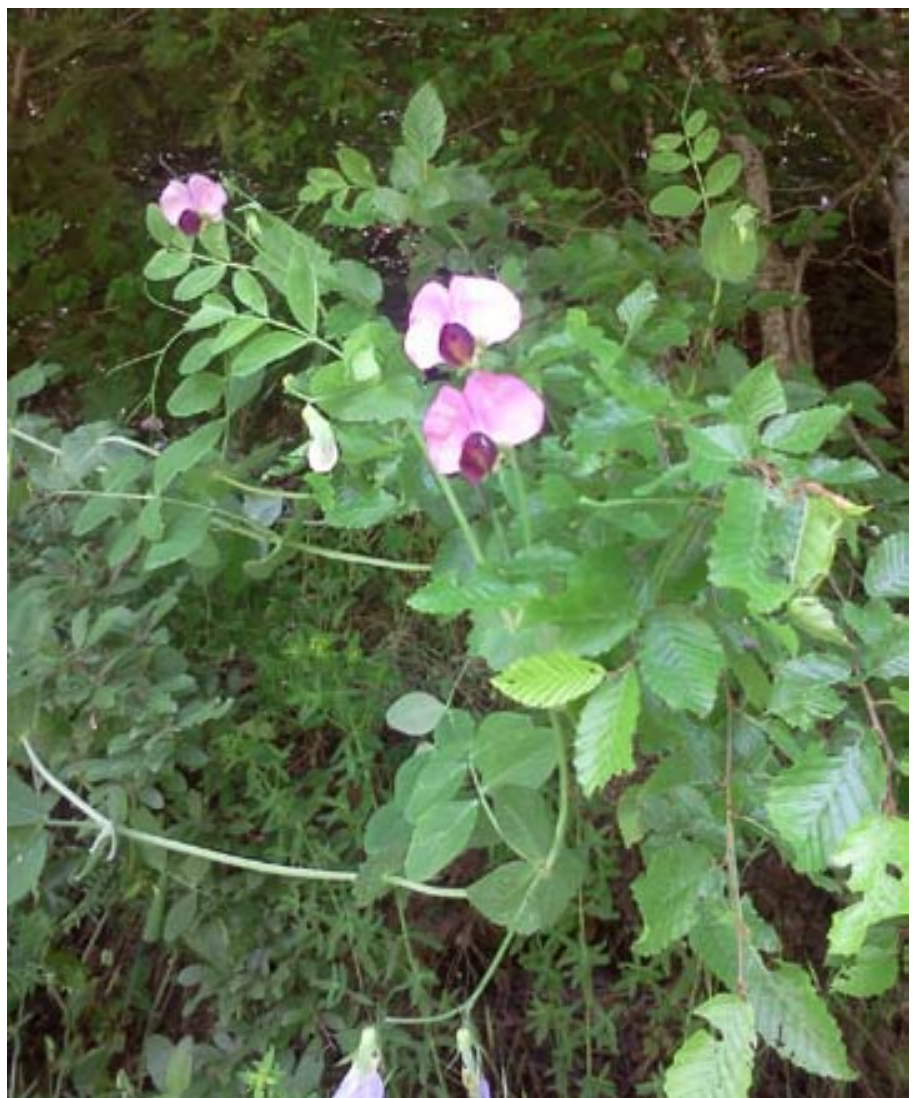

Figure 4. A wild population of 'tall' pea in the woods of the mountain Kozjak in southeast Serbia in May 2011 (Photo: Aleksandar Mikić)

Table 3. In situ agronomic characteristics of the 'tall' pea population from the upper flow of the river Pčinja in southern Serbia in 2011 related to forage (Ćupina et al. 2011)

$\begin{array}{llllllll} & \begin{array}{l}\text { Stem } \\ \text { length }(\mathrm{cm})\end{array} & \begin{array}{l}\text { Number } \\ \text { of stems } \\ \left(\text { plant }^{-1}\right)\end{array} & \begin{array}{l}\text { Stem mass } \\ \left(\mathrm{g} \mathrm{plant}^{-1}\right)\end{array} & \begin{array}{l}\text { Leaf mass } \\ \left(\mathrm{g} \mathrm{plant}^{-1}\right)\end{array} & \begin{array}{l}\text { Plant mass } \\ \left(\mathrm{g} \mathrm{plant}^{-1}\right)\end{array} & \begin{array}{l}\text { Stem } \\ \text { proportion }\end{array} & \begin{array}{l}\text { Leaf } \\ \text { proportion }\end{array} \\ \text { Minimum } & 31 & 1 & 4.48 & 7.70 & 12.18 & 0.13 & 0.48 \\ \text { Maximum } & 192 & 8 & 35.14 & 63.42 & 98.56 & 0.52 & 0.87 \\ \text { Average } & 68 & 3.8 & 11.04 & 22.44 & 33.48 & 0.33 & 0.67\end{array}$

Table 4. In situ agronomic characteristics of the 'tall' pea population from the upper flow of the river Pčinja in southern Serbia in 2011 related to grain (Ćupina et al. 2011)

\begin{tabular}{|c|c|c|c|c|c|c|c|c|c|c|}
\hline Stage 2 & $\begin{array}{l}\text { Stem } \\
\text { length } \\
(\mathrm{cm})\end{array}$ & $\begin{array}{l}\text { Number } \\
\text { of stems } \\
\left(\text { plant }^{-1}\right)\end{array}$ & $\begin{array}{l}\text { Number } \\
\text { of pods } \\
\left.\text { (plant }^{-1}\right)\end{array}$ & $\begin{array}{l}\text { Number } \\
\text { of } \\
\text { grains } \\
\left.\text { (plant }^{-1}\right)\end{array}$ & $\begin{array}{l}\text { Stem } \\
\text { mass ( } g \\
\left.\text { plant }^{-1}\right)\end{array}$ & $\begin{array}{l}\text { Leaf } \\
\text { mass ( } g \\
\left.\text { plant }^{-1}\right)\end{array}$ & $\begin{array}{l}\text { Pod } \\
\text { mass ( } g \\
\left.\text { plant }^{-1}\right)\end{array}$ & $\begin{array}{l}\text { Grain } \\
\text { mass ( } g \\
\text { plant }^{-1} \text { ) }\end{array}$ & $\begin{array}{l}\text { Plant } \\
\text { mass ( } g \\
\left.\text { plant }^{-1}\right)\end{array}$ & $\begin{array}{l}\text { Harvest } \\
\text { index }\end{array}$ \\
\hline Minimum & 52 & 1 & 2 & 12 & 2.82 & 1.28 & 0.61 & 2.46 & 7.17 & 0.34 \\
\hline Maximum & 168 & 7 & 11 & 74 & 14.34 & 5.25 & 2.35 & 15.71 & 37.65 & 0.42 \\
\hline Average & 72 & 4.1 & 4.3 & 27.3 & 5.52 & 2.38 & 1.24 & 5.60 & 14.74 & 0.38 \\
\hline
\end{tabular}


Table 5. In situ nutritive value of the 'tall' pea population from the upper flow of the river Pčinja in southern Serbia in 2011 (Ćupina et al. 2011)

\begin{tabular}{|c|c|c|c|c|c|c|c|c|}
\hline & $\begin{array}{l}\mathrm{Crud} \mathrm{e} \\
\text { protein }\end{array}$ & $\begin{array}{l}\text { Crude } \\
\text { fat }\end{array}$ & $\begin{array}{l}\text { Crud e } \\
\text { fiber }\end{array}$ & NDF & $\mathrm{ADF}$ & Lignin & $\begin{array}{l}\text { C r u d e } \\
\text { ash }\end{array}$ & NFC \\
\hline \multicolumn{9}{|c|}{ Flowering } \\
\hline Stem & 115 & 8 & 483 & 619 & 532 & 136 & 61 & 333 \\
\hline Leaf & 244 & 25 & 265 & 353 & 320 & 62 & 76 & 391 \\
\hline Plant & 201 & 19 & 337 & 441 & 390 & 86 & 71 & 372 \\
\hline$L S D_{0.05}$ & 32 & 6 & 123 & 45 & 35 & 15 & 6 & 29 \\
\hline \multicolumn{9}{|c|}{ Maturity } \\
\hline Stem & 69 & 12 & 528 & 674 & 587 & 128 & 88 & 303 \\
\hline Leaf & 146 & 41 & 291 & 324 & 307 & 76 & 131 & 390 \\
\hline Pod & 98 & 5 & 437 & 573 & 415 & 93 & 70 & 391 \\
\hline Grain & 343 & - & 188 & 242 & 205 & 19 & - & - \\
\hline$L S D_{0.05}$ & 67 & 11 & 211 & 69 & 55 & 27 & 33 & 31 \\
\hline
\end{tabular}

quality (Tables 3, 4 and 5).

'Tall' pea may be used in animal feeding as a quality source of plant protein. A test with feeding mirror carp (Cyprinus carpio L.) showed that both raw and heat-treated seeds of 'tall' pea may be an alternative ingredient in feeding carp, with up to $10 \%$ of raw seeds and more than $10 \%$ if the seeds are heat-treated (Buyukcapar \& Kamalak 2010). The wild populations of 'tall' pea also have nutraceutical properties and may be used in pharmaceutical industry (Tiwari 2008).

In isolated regions, there is a concurrent evolution of the wild populations of 'tall' pea and its indigenous Rhizobium populations. In the agroecological conditions of Europe, the strains of Rhizobium leguminosarum (Frank 1879) Frank 1889 , effective in the cultivated common pea, are ineffective in the wild populations of 'tall' pea from Near East. However, if inoculated with the strains also from Near East, there will be an effective nodulation in the wild populations of 'tall' pea originally from the same region (Lie et al. 1982).

In an extensive study of the wild populations of 'tall' pea from 42 countries in north-western USA, it was shown that they were a source of the resistance to Fusarium wilt, one of the major fungal diseases of the cultivated pea, caused by Fusarium oxysporum Schl. f. sp. pisi Snyd. \& Hans (McPhee et al. 1999). Mycosphaerella blight is also one of the most important diseases of the cultivated pea, reducing seed yield and limiting the area where the cultivated pea may be grown. In a study in Saskatchewan, Canada, the wild populations of 'tall' pea had a promising resistance

to this disease and a potential to transgress this trait into cultivated common pea (Jha et al. 2012). A combined field trial and laboratory analysis in Georgia and USA revealed a susceptibility of the wild populations of 'tall' pea from Georgia to Ascochyta blight (Chilvers et al. 2007). In a similar test carried out in Bulgaria, there was detected the presence of Mycosphaerella blight in the wild populations of 'tall' pea from the country (Kaiser et al. 2008). The wild populations of 'tall' pea also show a moderate resistance to nematodes, such as Heterodera goettingiana (di Vito \& Greco 1994). Both full and partial resistance to various diseases of the wild populations of 'tall' pea witnesses its status of semi-domesticated Pisum taxon.

\section{Large-flowered vetch (Vicia grandiflora Scop.)}

Large-flowered vetch is widely distributed over the regions with temperate climates in both Old and New World. It is a wild species that germinates in late summer or early autumn and is noticeable for its extreme tolerance to the length and intensity of low temperatures during the winter (DeGregorio et al. 1995). Recently it has been shown that the wild populations of large-flowered vetch may be used for forage production (Ćupina et al. 2007). By this reason, a collection of about 1000 wild populations and breeders lines of large-flowered vetch, mostly from numerous regions of Serbia, was established at the Institute of Field and Vegetable Crops in 2007 , with a primary goal of characterisation of various qualitative traits and evaluating diverse 
Table 6. Three-year average values of number of days from sowing to first flower, forage yield components, forage yield dry matter and forage dry matter proportion in the tested large-flowered vetch wild populations at Rimski Šančevi in 2005-2008 (Mikić et al. 2013a)

\begin{tabular}{|c|c|c|c|c|c|c|}
\hline Population & $\begin{array}{l}\text { Number of } \\
\text { days from } \\
\text { sowing to } \\
\text { first flower }\end{array}$ & $\begin{array}{l}\text { Main stem } \\
\text { length }(\mathrm{cm})\end{array}$ & $\begin{array}{l}\text { Number } \\
\text { of stems } \\
\left(\text { plant }^{-1}\right)\end{array}$ & $\begin{array}{l}\text { Number of } \\
\text { internodes } \\
\left(\text { plant }^{-1}\right)\end{array}$ & $\begin{array}{l}\text { Forage } \\
\text { dry matter } \\
\text { yield } \\
\left(\mathrm{t} \mathrm{ha}^{-1}\right)\end{array}$ & $\begin{array}{l}\text { Forage } \\
\text { dry matter } \\
\text { proportion }\end{array}$ \\
\hline Pasterova, Novi Sad, Serbia & 201 & 80 & 7 & 103 & 5.8 & 0.27 \\
\hline $\begin{array}{l}\text { Brankov most (Novi Beograd), } \\
\text { Belgrade }\end{array}$ & 211 & 70 & 11 & 126 & 5.4 & 0.30 \\
\hline Proleterske solidarnosti, Belgrade & 205 & 92 & 17 & 198 & 8.0 & 0.23 \\
\hline Ada Ciganlija, Belgrade & 208 & 40 & 9 & 76 & 2.8 & 0.39 \\
\hline Rumenački put, Novi Sad & 199 & 45 & 12 & 121 & 2.6 & 0.26 \\
\hline Novo groblje, Novi Sad & 208 & 47 & 6 & 68 & 2.9 & 0.24 \\
\hline $\begin{array}{l}\text { Dunavski kej (Novi Beograd), } \\
\text { Belgrade }\end{array}$ & 210 & 75 & 14 & 170 & 7.7 & 0.26 \\
\hline Ušće, Belgrade & 200 & 80 & 16 & 185 & 7.1 & 0.25 \\
\hline Fortress, Petrovaradin & 202 & 62 & 6 & 72 & 4.3 & 0.29 \\
\hline Trandžament, Petrovaradin & 211 & 65 & 12 & 151 & 6.2 & 0.27 \\
\hline $\begin{array}{l}\text { Boulevard Georges Clemenceau, } \\
\text { Dijon }\end{array}$ & 207 & 62 & 21 & 258 & 5.2 & 0.26 \\
\hline Partizanskih baza, Novi Sad & 207 & 77 & 14 & 315 & 7.1 & 0.25 \\
\hline Average & 206 & 66 & 12 & 154 & 5.4 & 0.27 \\
\hline$L S D_{0.05}$ & 6 & 7 & 1 & 22 & 1.5 & 0.03 \\
\hline$L S D_{0.01}$ & 9 & 10 & 2 & 30 & 1.8 & 0.04 \\
\hline
\end{tabular}

Table 7. Three-year average values of seed yield components and seed yield in the tested large-flowered vetch wild populations at Rimski Šančevi in 2005-2008 (Mikić et al. 2013a)

\begin{tabular}{|c|c|c|c|c|c|c|}
\hline Population & $\begin{array}{l}\text { Number of } \\
\text { days from } \\
\text { sowing to } \\
\text { first mature } \\
\text { pod }\end{array}$ & $\begin{array}{l}\text { Number of } \\
\text { fertile nodes } \\
\left(\text { plant }^{-1}\right)\end{array}$ & $\begin{array}{l}\text { Number of } \\
\text { pods } \\
\left.\text { (plant }{ }^{-1}\right)\end{array}$ & $\begin{array}{l}\text { Number } \\
\text { of seeds } \\
\text { (plant }^{-1} \text { ) }\end{array}$ & $\begin{array}{l}\text { Thousand } \\
\text { seed mass } \\
\text { (g) }\end{array}$ & $\begin{array}{l}\text { Seed yield } \\
\left(\mathrm{kg} \mathrm{ha}^{-1}\right)\end{array}$ \\
\hline Pasterova, Novi Sad, Serbia & 222 & 6 & 7 & 24 & 16 & 418 \\
\hline $\begin{array}{l}\text { Brankov most (Novi Beograd), } \\
\text { Belgrade }\end{array}$ & 240 & 9 & 15 & 67 & 18 & 1134 \\
\hline Proleterske solidarnosti, Belgrade & 225 & 15 & 20 & 107 & 14 & 1285 \\
\hline Ada Ciganlija, Belgrade & 230 & 6 & 9 & 59 & 15 & 907 \\
\hline Rumenački put, Novi Sad & 219 & 15 & 37 & 165 & 14 & 2084 \\
\hline Novo groblje, Novi Sad & 224 & 5 & 5 & 31 & 16 & 537 \\
\hline $\begin{array}{l}\begin{array}{l}\text { Dunavski kej (Novi } \\
\text { Belgrade }\end{array} \\
\text { Beograd), }\end{array}$ & 241 & 12 & 14 & 81 & 18 & 856 \\
\hline Ušće, Belgrade & 225 & 14 & 19 & 90 & 19 & 1191 \\
\hline Fortress, Petrovaradin & 227 & 5 & 5 & 28 & 17 & 508 \\
\hline Trandžament, Petrovaradin & 229 & 10 & 12 & 56 & 16 & 877 \\
\hline $\begin{array}{l}\text { Boulevard Georges Clemenceau, } \\
\text { Dijon }\end{array}$ & 236 & 8 & 12 & 70 & 14 & 1061 \\
\hline Partizanskih baza, Novi Sad & 230 & 11 & 19 & 113 & 14 & 800 \\
\hline Average & 229 & 10 & 14 & 74 & 16 & 972 \\
\hline$L S D_{0.05}$ & 7 & 3 & 4 & 18 & 2 & 245 \\
\hline$L S D_{0.01}^{0.05}$ & 10 & 5 & 7 & 23 & 3 & 312 \\
\hline
\end{tabular}




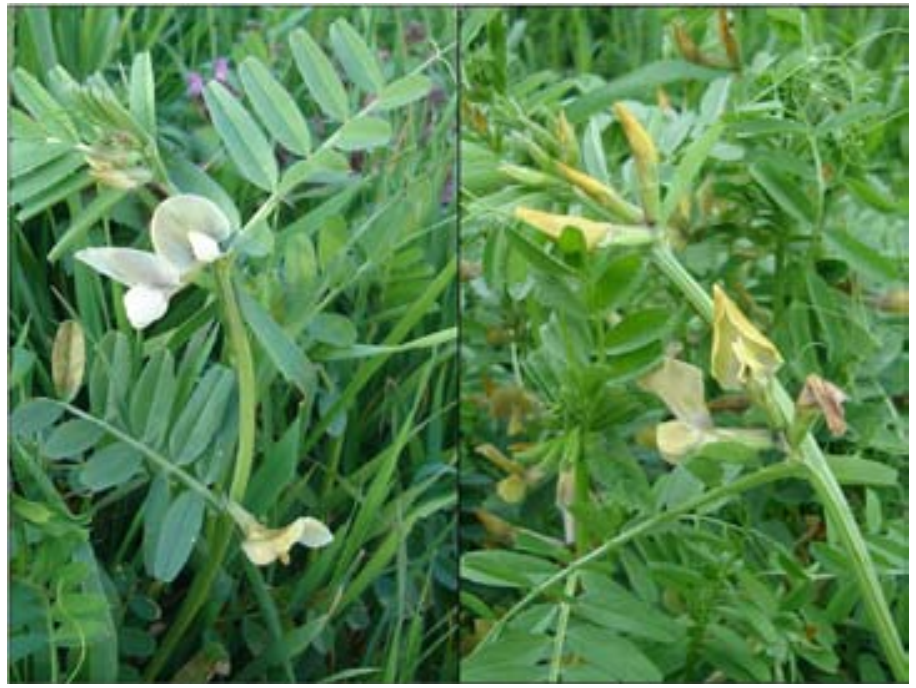

Figure 5. Wild type from the population MM 04/08 (left) and multi-podded mutant from the population MM 03/10 (right) in large-flowered vetch (Mikić et al. 2013a) (Photos: Aleksandar Mikić)

agronomic characteristics.

The preliminary results of assessing the potential of large-flowered vetch for forage production demonstrated that some of its populations have a considerable ability to bring forth up to $40 \mathrm{t} \mathrm{ha}^{-1}$ of fresh forage (Mikić et al. 2009b). Another field trial carried out in the agroecological conditions in the northern Balkan Peninsula showed that some of the wild populations of large-flowered vetch may produce about $8 \mathrm{t} \mathrm{ha}^{-1}$ of forage dry matter (Table 6) and up to $2000 \mathrm{~kg} \mathrm{ha}^{-1}$ of seeds (Table 7), an important trait for commercialising a developed cultivar (Mikić et al. 2013a). All this provide a solid basis for beginning the breeding programmes on large-flowered vetch. The analysis of the mutual relationship among the followed characteristics revealed that forage dry matter yield is significantly and positively correlated to main stem length, number of fertile nodes, number of internodes, and number of leaves, as well as significantly and negatively correlated to number of plants after winter. Seed yield was significantly and positively correlated to number of pods, number of seeds, number of stems and number of fertile nodes.

Large-flowered vetch suffers from the same insufficiencies like common and other Vicia species, with indeterminate stem growth, poor standing ability and non-uniform maturity. In order to significantly improve the seed production in large-flowered vetch and make it both reliable for market and economically justified, several solutions may be proposed. One of them is to identify the gene(s) responsible for a determinate stem growth, where each stem at one point would end with flowers and not growing ceaselessly, that would be ortholog(s) to the genes in pea such as $D E T$, present in all contemporary common pea cultivars. Another is to focus on the fixation of said trait of forming more than two pods per fertile node (Figure 5), most likely under the control of ortolog(s) to $F N$ and $F N A$ in common pea (Mikić et al. 2013a).

\section{Tiny vetch (Vicia hirsuta (L.) Gray)}

Tiny vetch is a species that shares the same number of chromosomes as the majority of those from the tribe Fabae, $2 n=14$ (Terziiski \& Dimitrov 1983). The charred seeds of tiny vetch were found together with those of spelt (Triticum aestivum L. subsp. spelta (L.) Thell.) in a Bell Beaker site in Switzerland dated back in third millennium BCE (Akeret et al. 2005). Tiny vetch is often regarded as a weedy species, with one of the most rapid growth on undisturbed soils in comparison to other plants (Roberts \& Bodrell 1985) and in organic farming (Rydberg \& Milberg 2000). On the other hand, the wild populations of tiny vetch are considered beneficial in permanent grasslands and meadows, where they contribute to the quality of grazed biomass (Tomić et al. 2005b).

The genetic resources of tiny vetch are rich, but this species is rarely a member of the most of gene banks. Collecting wild populations of tiny vetch in Serbia began a decade ago, with more than 50 accessions so far and maintained at the Institute of Field and Vegetable Crops in Novi Sad (Mihailović et al. 2007). They are evaluated for the most important morphological and agronomic characteristics (Table 8), with the most promising 
Table 8. Some traits in a wild population of tiny vetch and other vetches collected in the mountain Fruška Gora (Krstić et al. 2007)

\begin{tabular}{|c|c|c|c|c|}
\hline Species & $\begin{array}{l}\text { Plant height } \\
(\mathrm{cm})\end{array}$ & $\begin{array}{l}\text { Number of seeds } \\
\text { in pod }\end{array}$ & $\begin{array}{l}\text { Seed size } \\
(\mathrm{mm})\end{array}$ & $\begin{array}{l}\text { Thousand seeds } \\
\text { mass } \\
\text { (g) }\end{array}$ \\
\hline$V$. biennis & $100-150$ & $4-6$ & $2.5-3$ & \\
\hline V. cassubica & & & -4 & \\
\hline V. cracca & $30-50$ & $4-8$ & $2.5-3.4$ & $11-15$ \\
\hline$V$. dumetorum & $60-250$ & $3-8$ & $5-6$ & \\
\hline V. hirsuta & $30-60$ & $1-3$ & $1.5-3$ & $4.1-6.2$ \\
\hline V. incana & & & $2.5-3.5$ & \\
\hline V. lathyroides & $5-20$ & $5-8$ & $1.5-2$ & 2.5 \\
\hline V.lutea & $20-70$ & $3-9$ & 3 & $30-40$ \\
\hline$V \cdot$ peregrina & $20-100$ & $4-6$ & $5-6$ & \\
\hline$V \cdot$ pisiformis & $100-200$ & $6-7$ & -5 & $25-35$ \\
\hline V.sepium & $30-50$ & $3-7$ & $3-4.5$ & $24-27$ \\
\hline V. sylvatica & $100-200$ & $4-5$ & -4 & $30-35$ \\
\hline V. tenuifolia & $60-150$ & $4-7$ & $2.8-3.6$ & $18-21$ \\
\hline V. tetrasperma & $30-60$ & -4 & $1.5-2$ & $4.2-5$ \\
\hline V.truncatula & $35-50$ & $2-5$ & & \\
\hline
\end{tabular}

populations being a source of the lines that may be developed into advanced cultivars (Krstić et al. 2007). The proportion of leaves in the total fresh forage in the wild populations of tiny vetch may be higher than $45 \%$, with a leaf dry matter crude protein content of more than $260 \mathrm{~g} \mathrm{~kg}^{-1}$ and with nearly $0.6 \mathrm{mg} \mathrm{g}^{-1}$ of caretonoids (Sliesaravičius et al. 2007). The wild populations of tiny vetch may be of interested in genomic research and the analysis of synteny with other, much more economically important Vicia crops, such as in an analysis of the genetic control and expression of a glycine-rich early nodulin (Küster et al. 1995).

In Serbia, first attempts have been made in intercropping the wild populations of tiny vetch with other cool season annual legumes of the similar growth habit, such as common pea. The wild populations of tiny vetch may also be intercropped with cereals, such as in the trials in Iran with barley or triticale $(\times$ Triticosecale Wittm. ex A. Camus) (Sharma et al. 1978) and in India with oat (Avena sativa L.) (Prasad \& West 1996). In a test aimed at assessing the effects of interactions between insect root feeders, VesicularArbuscular Mycorrhizal fungi and soil fertility on the establishment, growth and reproduction of a wild population tiny vetch, it was shown that non-additive interactions between ecological factors in the soil environment may strongly affect plant performance. This may be explained by the impact of natural levels of soil fertility biotic factors, such as mycorrhizal fungi and soil- dwelling insects, important in shaping the plant community of various Vicia species (Ganade \& Brown 1997).

Although it attacks numerous Vicia species, bean aphid (Megoura crassicauda Mordvilko) never infests the wild populations of tiny vetch, due to an extraction of a specific medium strongly inhibiting the salivary sheath formation (Ohta et al. 2006). In a similar way, the wild populations of tiny vetch are much less vulnerable to the attack of various herbivores, such as ants, than other annual legumes in the wild flora (Katayama \& Suzuki 2011). A moderate tolerance to brown field slug (Deroceras reticulatum Müller), an important pest in common wheat is assessed in the wild populations of tiny vetch (Brooks et al. 2003). They are also a source of the resistance to crenate broomrape, with only between $0 \%$ and $18 \%$ of infesting (Sillero et al. 2005b).

\section{Narrow-leafed vetch (Vicia sativa subsp. nigra (L.) Ehrh.)}

Common vetch comprises five subspecies, namely amphicarpa (L.) Batt., cordata (Wulfen ex Hoppe) Batt., macrocarpa (Moris) Arcang., nigra (L.) Ehrh. and sativa, with the fourth one, known as narrow-leafed or black-podded vetch, as the most widely distributed of all (Maxted 1995).

An annual legumes collection of the Institute of Field and Vegetable Crops in Novi Sad, Serbia, is constantly enriched with the local landraces and 
Table 9. Average values of forage yields in ten wild populations of narrow-leafed vetch for the years of 2006 and 2007 at Rimski Šančevi (Mikić et al. 2008)

\begin{tabular}{|c|c|c|c|c|c|}
\hline Population & $\begin{array}{l}\text { Green forage } \\
\text { yield } \\
\left(\text { g plant }^{-1}\right)\end{array}$ & $\begin{array}{l}\text { Green forage } \\
\text { yield } \\
\left(\mathrm{t} \mathrm{ha}^{-1}\right)\end{array}$ & $\begin{array}{l}\text { Forage dry matter } \\
\text { yield } \\
\left(\text { g plant }^{-1}\right)\end{array}$ & $\begin{array}{l}\text { Forage dry matter } \\
\text { yield } \\
\left(\mathrm{t} \mathrm{ha}^{-1}\right)\end{array}$ & $\begin{array}{l}\text { Forage dry matter } \\
\text { proportion }\end{array}$ \\
\hline MM 02/01 & 12.24 & 18.4 & 3.32 & 5.0 & 0.27 \\
\hline MM 02/02 & 22.27 & 33.4 & 4.84 & 7.3 & 0.22 \\
\hline MM 02/03 & 9.11 & 13.7 & 2.90 & 4.3 & 0.32 \\
\hline MM 02/04 & 9.66 & 14.5 & 2.92 & 4.4 & 0.30 \\
\hline MM 03/08 & 11.57 & 17.4 & 3.32 & 5.1 & 0.29 \\
\hline MM 03/09 & 10.50 & 15.8 & 3.35 & 5.1 & 0.32 \\
\hline MM 03/11 & 9.43 & 14.1 & 3.34 & 5.0 & 0.35 \\
\hline MM 03/17 & 15.40 & 23.1 & 2.87 & 4.2 & 0.19 \\
\hline MM 05/08 & 14.12 & 21.2 & 2.92 & 4.4 & 0.21 \\
\hline MM 05/09 & 13.04 & 19.6 & 3.34 & 5.0 & 0.26 \\
\hline $\mathrm{LSD}_{0.05}$ & 3.18 & 4.8 & 0.78 & 1.1 & 0.05 \\
\hline $\mathrm{LSD}_{0.01}$ & 5.03 & 6.3 & 1.23 & 1.7 & 0.08 \\
\hline
\end{tabular}

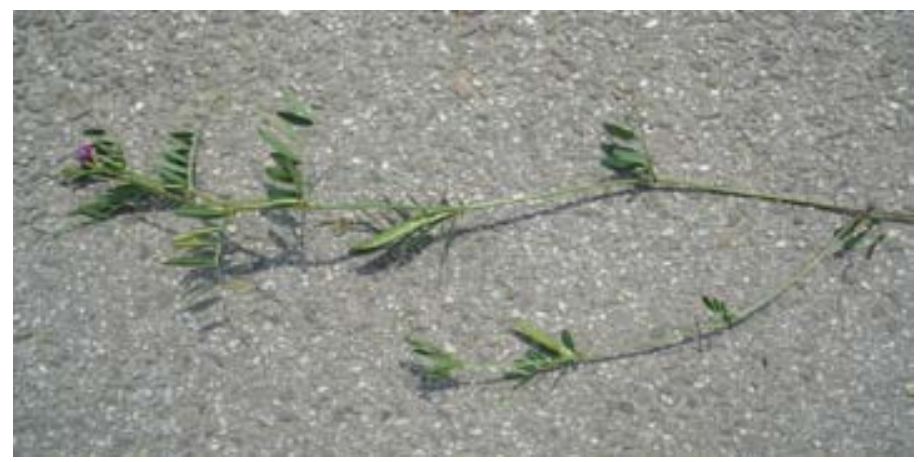

Figure 6. A typical plant of narrow-leafed vetch, the population MM 05/09 from Novi Sad, Serbia, with undesirable traits for commercialization, such as indeterminate stem growth and non-uniform maturity (Photos: Aleksandar Mikić)

wild populations of narrow-leafed vetch of Serbian origin, mostly collected in the region of Novi Sad and the mountain of Fruška Gora (Tomić et al. 2005a). Today, it contains more than 1,000 accessions, maintained in the field conditions and multiplied for the needs of characterisation and evaluation of the economically most important characteristics.

The preliminary results of a series of field trials with the initially collected wild populations of narrow-leafed vetch show that some of them have a considerable potential for forage production (Table 9), with more than $20 \mathrm{tha}^{-1}$ and even about $30 \mathrm{tha}^{-1}$ of fresh forage and more than $5 \mathrm{t} \mathrm{ha}^{-1}$ of forage dry matter (Mikić et al. 2008). Narrowleafed vetch may also be used as cover crop with an excellent resistance to length and intensity of low temperatures and as green manure (Mikić et al., 2009c). Among the traits undesirable for breeders that are present in the wild populations of narrow-leafed are indeterminate stem growth and non-uniform maturity (Figure 6). These problems needs to be solved, either by searching for mutants or by selecting genotypes with possibly higher number of flowers and pods per node.

Very little is known about the nutritive value and the resistance of the wild populations of narrowleafed vetch to various forms of biotic stress.

\section{French vetch (Vicia serratifolia Jacq.)}

Earlier classifications considered French vetch as a subspecies of Narbonne vetch (Vicia narbonensis L.), but today it is mostly regarded as a separate species within the same section of the subgenus Vicia of the genus Vicia, together with Narbonne vetch (Maxted 1995). French vetch primarily originated in Near Eastern centre of diversity, 


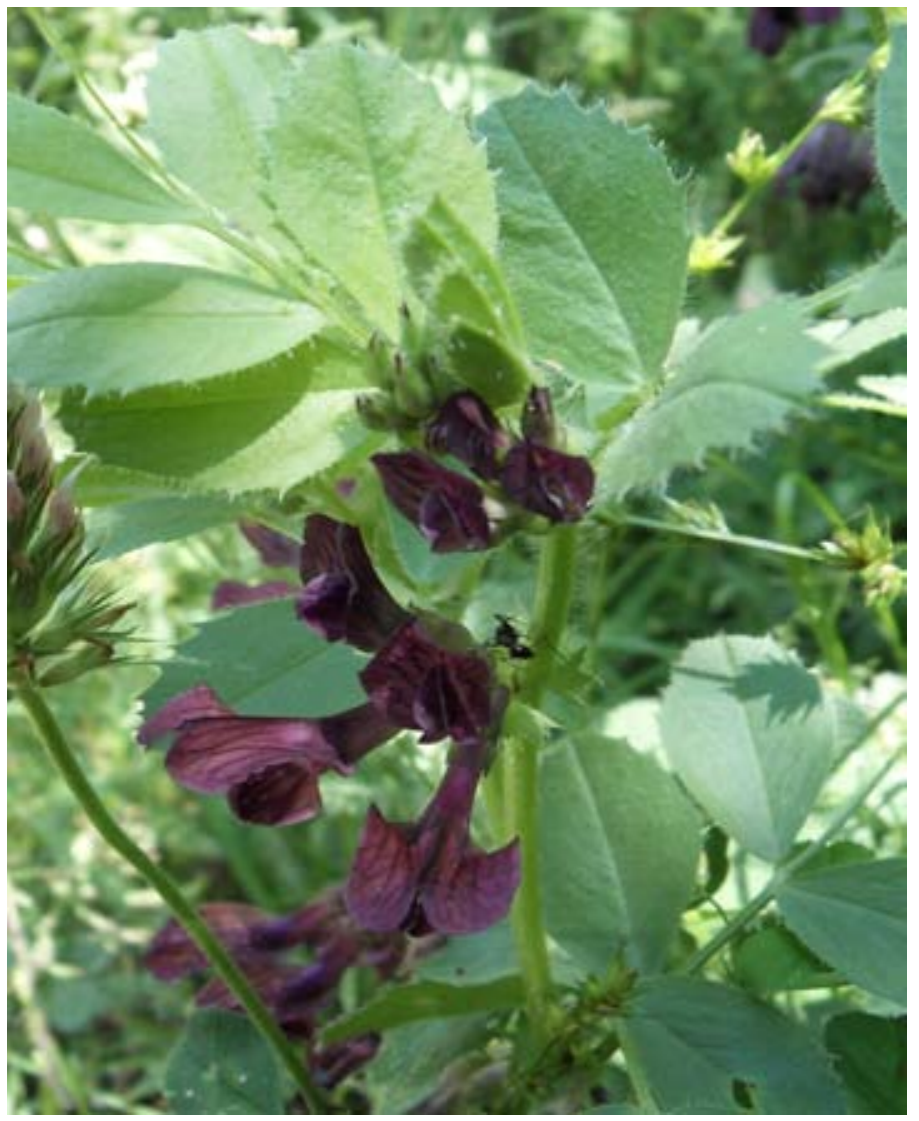

Figure 7. A plant of French vetch from a wild population in southeast Serbia, May 2011 (Photo: Petr Smýkal)

Table 10. Average values of forage yields in wild populations of French vetch for the years of 2010 and 2011 at Rimski Šančevi (Ćupina et al. 2012)

$\begin{array}{llllll}\text { Population } & \begin{array}{l}\text { Fresh forage yield } \\ \left(\mathrm{g} \mathrm{plant}^{-1}\right)\end{array} & \begin{array}{l}\text { Fresh forage yield } \\ \left(\mathrm{t} \mathrm{ha}^{-1}\right)\end{array} & \begin{array}{l}\text { Forage dry matter } \\ \text { yield }\left(\mathrm{g} \mathrm{plant}^{-1}\right)\end{array} & \begin{array}{l}\text { Forage dry matter } \\ \text { yield }\left(\mathrm{t} \mathrm{ha}^{-1}\right)\end{array} & \begin{array}{l}\text { Foraged } \\ \text { propo }\end{array} \\ \text { VS 01 } & 18.99 & 27.2 & 4.27 & 6.1 & 0.23 \\ \text { VS 02 } & 24.74 & 36.1 & 5.81 & 8.5 & 0.24 \\ \text { VS 03 } & 12.95 & 18.4 & 3.24 & 4.6 & 0.25 \\ \text { VS 04 } & 6.12 & 9.0 & 1.44 & 2.1 & 0.24 \\ \text { VS 05 } & 29.30 & 41.6 & 6.74 & 9.6 & 0.23 \\ \text { VS 06 } & 16.85 & 24.3 & 4.04 & 5.8 & 0.24 \\ \text { VS 07 } & 22.07 & 30.7 & 4.99 & 6.9 & 0.23 \\ \text { VS 08 } & 12.07 & 17.1 & 3.38 & 4.8 & 0.28 \\ \text { VS 09 } & 20.94 & 29.9 & 4.82 & 6.9 & 0.23 \\ \text { VS 10 } & 16.23 & 23.9 & 3.90 & 5.7 & 0.24 \\ \text { VS 11 } & 22.53 & 33.3 & 5.50 & 8.1 & 0.24 \\ \text { VS 12 } & 19.63 & 29.2 & 4.65 & 6.9 & 0.24 \\ \text { Mean } & 18.54 & 26.7 & 4.40 & 6.3 & 0.24 \\ \text { LSD }_{0.05} & 5.67 & 8.2 & 1.36 & 1.9 & 0.03\end{array}$


with the Mediterranean as the secondary one and the number of chromosomes of $2 n=14$ (Şahin \& Babaç 1990). Apart from Narbonne vetch, it is also taxonomically very close to Vicia johannis Tamamsch. (Van de Ven 1993). Both French vetch and Narbonne vetch are the closest botanical relatives with faba bean. However, a chemotaxonomic investigation of leaf flavonoids by paper chromatography showed that faba bean is rather distinct from both (Perrino et al. 1991). Apart from morphological differences, such as leaf indentation present in French vetch, they differ from each other by alternate orthozymes (Jaaska \& Leht 2007).

Although some reports indicate that French vetch has little to offer to agronomy in the east Mediterranean countries (Berger et al. 2002), series of trials with the wild populations of French vetch (Ćupina et al. 2012), collected in various regions of Serbia (Figure 7), demonstrated that some of them may produce at least $20 \mathrm{tha}^{-1}$ of green forage and more than $6 \mathrm{t} \mathrm{ha}^{-1}$ (Table 10). In an analysis of the presence of various anti-nutritive factors in the grain of the wild populations of various Vicia species, such as condensed tannins, phenolics and proteinase inhibitors, French vetch had lower concentrations in comparison to many other included in the same test (Berger et al. 2003).

The wild populations of French vetch are reported to be resistant to both length and intensity of low temperatures (Birch et al. 1985). They also may be a potential source to Uromyces viciaefabae (Pers.) J. Schröt and U. pisi, with little known and confirms host specialization within $U$. viciaefabae, with limited knowledge on the specificity of these interactions (Rubiales et al. 2013). At the same time, the wild populations of French vetch demonstrated higher levels of resistance to black bean aphid (Aphis fabae Scopoli) than in the closely related cultivated crop, faba bean, with a significant intraspecific variability of this trait. The wild populations of French vetch differ to a great extent in the resistance to crenate broomrape, ranging from no broomrape plants attached to the French vetch plants to a high degree of infestation (Sillero et al. 2005b).

\section{'Beautiful' vavilovia (Vavilovia formosa (Stev.) Fed.)}

The first report on the existence of 'beautiful' vavilovia (syn. Pisum formosum (Stev.) Alef.), originally named Orobus formosus Stev., was made in 1812 (Mikić et al. 2009d). It is the only species of the genus Vavilovia Fed., the fifth member of the tribe Fabeae (formerly Vicieae), together with genera Lathyrus L., Lens Mill.,
Pisum L.and Vicia L. (Kenicer et al. 2009). There have been reports on a certain intraspecific variability, which led to a distinction of few hypothetic subtaxa, such as Orobus formosus var. microphyllus Ser. or Pisum formosum var. pubescens with sparsely pubescent leaflets (Sinjushin \& Belyakova 2010). The centre of the geographical distribution of 'beautiful' vavilovia is the Central and Eastern Caucasus, with a disjunct distribution across neighbouring mountainous areas, and comprising mutually isolated shale or rocky substrate regions with an altitude between $1500 \mathrm{~m}$ and $3500 \mathrm{~m}$ in Northern Ossetia, Cabardino-Balkaria, Karachevo-Cherkessia and Dagestan in the Russian Federation and Armenia, Azerbaijan, Georgia, Iran, Iraq, Lebanon, Syria and Turkey (Akopian et al. 2010).

Since nearly all attempts to multiply the seeds of 'beautiful' vavilovia in ex situ conditions were either quite short-lived or without any success, there is no gene bank with the wild populations of 'beautiful' vavilovia. The only source for any botanical, molecular or other kind of research are few herbarium collections with the specimens of various populations of 'beautiful' vavilovia. By this reason, there is a strong and urgent need for establishing a long-term strategy of its in situ conservation, especially in the regions where it grows abundantly. The greatest threat to the survival of 'beautiful' vavilovia represent wild and nomadic domestic animals that graze it, attracted by its good palatability, while on poorer soils mice may prevent the regeneration and multiplication of 'beautiful' vavilovia by eating its shattered seeds (Mikić et al. 2011). So far, the only successful example of an ex situ conservation of 'beautiful' vavilovia is within the Flora and Vegetation of Armenia plot of the Yerevan Botanic Garden, made in 2009 and currently only in a vegetative stage.

Since 'beautiful' vavilovia has the same number of chromosomes as majority of the species belonging to the genera Lathyrus, Pisum and Vicia, there is possibility for their hybridisation. There were speculations that a hypothetical gene for perenniality, present in 'beautiful' vavilovia, might be introgressed into its cultivated relatives, especially common pea, and thus be of a particular interest for breeders (Mikić et al. 2010). The only known reports about crossings between 'beautiful' vavilovia and other Fabeae come from the N. I. Vavilov Institute of Plant Industry in St. Petersburg and its station in Dagestan (Golubev 1990). The hybridisation of ' 'beautiful’ vavilovia $\mathrm{x}$ 'common pea resulted 


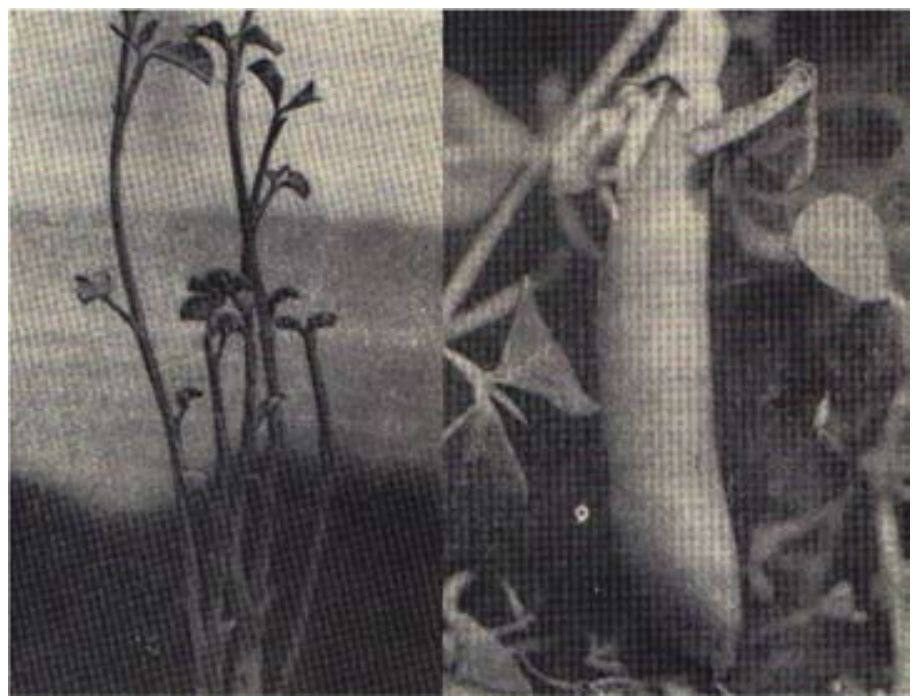

Figure 8. $\mathrm{A} \mathrm{F}_{1}$ hybrid $Q$ 'beautiful' vavilovia $\times \widehat{\jmath}$ common pea plant $(\mathrm{left})$ and a pod of a $\mathrm{F}_{1}$ hybrid $\odot$ common pea plant त̄' 'beautiful' vavilovia $\times$ (right) (Golubev 1990) (Photos: Alexandr Golubev)

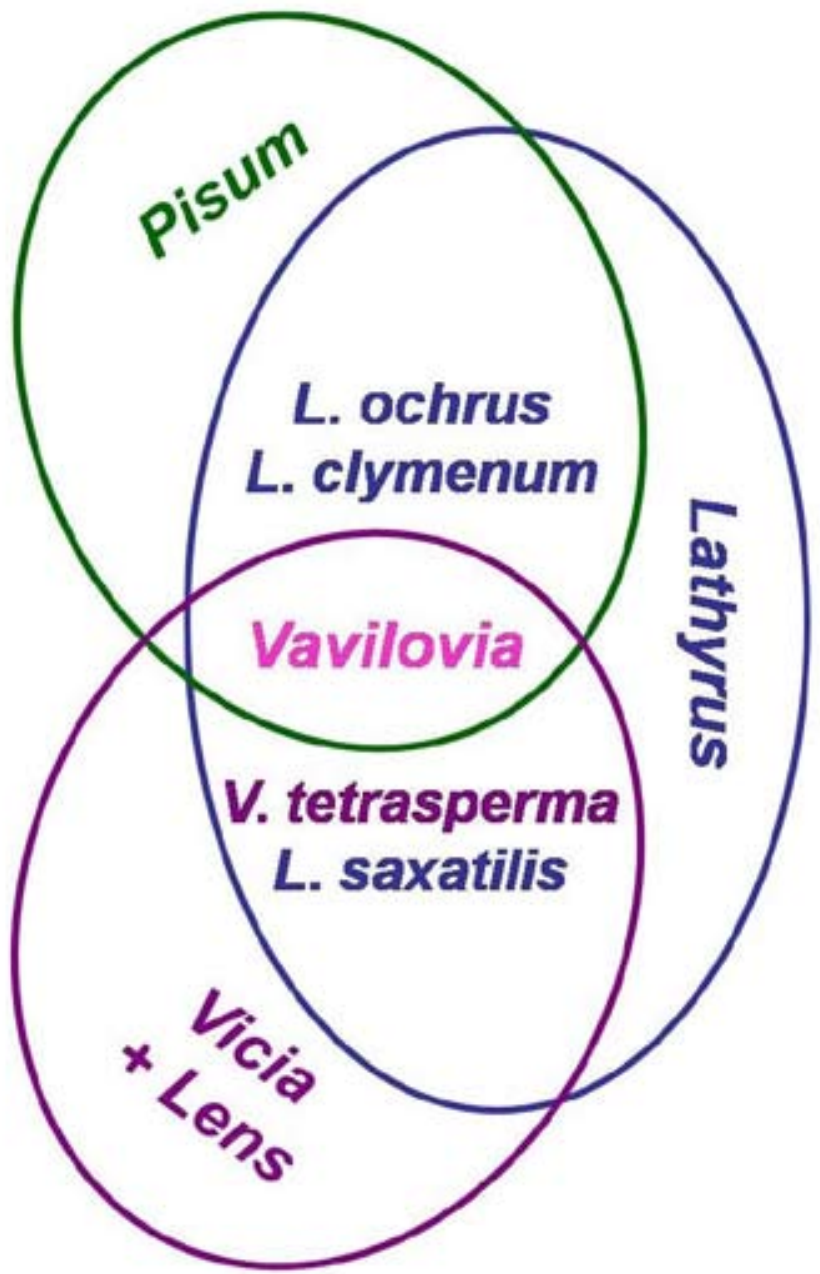

Figure 9. Phylogeny of the tribe Fabeae based upon molecular tools (Mikić et al. 2013c) 
in several normally developed $\mathrm{F}_{1}$ seeds and only one a true $F_{1}$ hybrid plant. It had several basal branches with long internodes and no lateral branches typical for vavilovia, compound leaves with one pair of leaflets and, instead of the mucro-like organ present in vavilovia, a third and smaller leaflet, resembling the trifoliolate leaves of Medicago or Trifolium species (Figure 8, left). This $F_{1}$ plant did not enter the generative stage and eventually withered due to chlorosis. A reciprocal combination of $q P$. sativum $\mathrm{x} \delta$ 'beautiful' vavilovia also produced one $\mathrm{F}_{1}$ hybrid plant, with numerous basal and lateral branches much longer than common pea and 'beautiful' vavilovia. Unlike the $F_{1}$ plant from the opposite combination, this one had flowers and five pods, with all the $\mathrm{F}_{2}$ seeds aborted in two and $\mathrm{F}_{2}$ seeds remaining immature in the other three (Figure 8 , right). Behind A. A. Golubev remained some personal communications that crossings between 'beautiful' vavilovia and its closest relatives, such as red-yeallow pea, were more successful if 'beautiful' vavilovia is used as the male parent (Maxted \& Ambrose 2001).

One of the first applications of molecular tools in resolving the issue of the exact position of 'beautiful' vavilovia and the taxonomy of the tribe Fabeae was based upon herbarium specimens of this and about 30 other species of all other genera of the tribe (Mikić et al. 2013c). This analysis chose four phylogenetically informative regions, namely chloroplast maturase $\mathrm{K}$, trn $\mathrm{L}-\mathrm{F}$ and trn $\mathrm{S}-\mathrm{G}$ fragments and the internal transcribed spacer (ITS) region of nuclear DNA. Both maximum parsimony and Bayesian analysis of combined sequence produced the data showing that 'beautiful' vavilovia had a distinct status within the same clade as Lathyrus and Pisum (Figure 9). On the other hand, the evidence on the possibility to produce hybrids between 'beautiful' vavilovia and common pea, together with a susceptibility of 'beautiful' vavilovia to Uromyces pisi and Ascochyta pinodes, was used to show that the status of 'beautiful' vavilovia as a separate genus is still not confirmed (Yan'kov \& Golubev 1999).

\section{Conclusions}

Legume crop wild relatives represent a wide gene pool of various desirable traits, especially those related to abiotic and biotic stress resistance that may be introgressed into the advanced cultivars, with overcoming potential physiological or genetic barriers. The wide mutual variations of the most important characteristics may be extremely beneficial for the advanced cultivars due to numerous bottlenecks and their narrow genetic base. If considered from a wider point of view, wild relatives of cool season annual legumes represent not only a national or regional treasury, but also a tool to improve the modern agriculture to the benefit of the whole mankind. They grow so near to us and among us and collecting them and using them in a sustainable way, especially by breeding, should be not an obstacle that may have a long-term consequences leading to their gradual degradation and final disappearance. 


\section{References}

Abbo, S., Zezak, I., Schwartz, E., Lev-Yadun, S., \& Gopher, A. (2008). Experimental harvesting of wild peas in Israel: implications for the origins of Near East farming. Journal of Archaeological Science 35: 922-929.

Abbo, S., Rachamim, E., Zehavi, Y., Zezak, I., Lev-Yadun, S., \& Gopher, A. (2011). Experimental growing of wild pea in Israel and its bearing on Near Eastern plant domestication. Annals of Botany 107: 1399-1404.

Ahmad, M., Russell, A.C., \& McNeil, D.L. (1997). Identification and genetic characterization of different resistance sources to Ascochyta blight within the genus Lens. Euphytica 97: 311315.

Akeret, Ö. (2005). Plant remains from a Bell Beaker site in Switzerland, and the beginnings of Triticum spelta (spelt) cultivation in Europe. Vegetation History and Archaeobotany 14: 279-286.

Akopian, J., Sarukhanyan, N., Gabrielyan, I., Vanyan, A., Mikić, A., Smýkal, P., Kenicer, G., Vishnyakova, M., Sinjushin, A., Demidenko, N., \& Ambrose, M. (2010). Reports on establishing an ex situ site for 'beautiful' vavilovia (Vavilovia formosa) in Armenia. Genetic Resources and Crop Evolution 57: 11271134.

Albrecht, H. (2003). Suitability of arable weeds as indicator organisms to evaluate species conservation effects of management in agricultural ecosystems. Agriculture, Ecosystems \& Environment 98: 201-211.

Al-Qura'n, S.A. (2010). Ethnobotanical and ecological studies of wild edible plants in Jordan. Libyan Agriculture Research Center Journal International 1: 231-243.

Ambrose, M.J. (2009). Screening for field resistance to powdery mildew (Erysiphe polygoni DC) in the JI Pisum collection. Pisum Genetics 41: 40-43.

Ambrose, M.J., \& Ellis, T.H.N. (2008). Ballistic seed dispersal and associated seed shadow in wild Pisum germplasm. Pisum Genetics 40: 5-10.

Balyan, R.S., Malik, R.K., \& Malik, R.S. (1991). Growth and development of Lathyrus aphaca, Vicia sativa and Cirsium arvense under different sowing dates. Haryana Journal of Agronomy 7: 136-139.

Bargali, K. (2011). Screening of leguminous plants for VAM association and their role in restoration of degraded lands. Journal of American Science 7: 7-11.

Barilli, E., Satovic, Z., Rubiales, D., \& Torres, A.M. (2010). Mapping of quantitative trait loci controlling partial resistance against rust incited by Uromyces pisi (Pers.) Wint. in a Pisum fulvum L. intraspecific cross. Euphytica 175: 151-159.

Bayaa, B., Erskine, W., \& Hamdi, A. (1994). Response of wild lentil to Ascochyta fabae f. sp. lentis from Syria. Genetic Resources and Crop Evolution 41: 61-65.

Berger, J.D., Robertson, L.D., \& Cocks, P.S. (2002). Agricultural potential of Mediterranean grain and forage legumes: Key differences between and within Vicia species in terms of phenology, yield, and agronomy give insight into plant adaptation to semi-arid environments. Genetic Resources and Crop Evolution 49: 313-325.

Berger, J.D., Robertson, L.D., \& Cocks, P.S. (2003). Agricultural potential of Mediterranean grain and forage legumes: 2) Anti-nutritional factor concentrations in the genus Vicia. Genetic Resources and Crop Evolution 50: 201-212.

Birch, N. (1985). Field evaluation of resistance to black bean aphid, Aphis fabae, in close relatives of the faba bean, Vicia faba. Annals of Applied Biology 106: 561-569.

Bogdanova, V.S., \& Kosterin, O.E. (2007). Hybridization barrier between Pisum fulvum Sibth. et Smith and P. sativum L. is partly due to nuclear-chloroplast incompatibility. Pisum Gene- tics 39: 8-9.

Bogdanova, V.S., Galieva, E.R., \& Kosterin, O.E. (2009). Genetic analysis of nuclear-cytoplasmic incompatibility in pea associated with cytoplasm of an accession of wild subspecies Pisum sativum subsp. elatius (Bieb.) Schmahl. Theoretical and Applied Genetics 118: 801-809.

Boža, P., Igić, R., Krstić, B., Mihailović, V., Anačkov, G., Vukov, D., \& Mikić, A. (2003). Distribution of the Lathyrus L. 1753 (Fabales, Fabaceae) species in the Vojvodina province. Proceedings for Natural Sciences, Matica Srpska, Novi Sad 104: 6181 .

Brooks, A.S., Crook, M.J., Wilcox, A., \& Cook, R.T. (2003). A laboratory evaluation of the palatability of legumes to the field slug, Deroceras reticulatum Müller. Pest Management Science 59: 245-251.

Buyukcapar, H.M., \& Kamalak, A. (2010). Nutritive value of wild pea (Pisum elatius) seed as a dietary protein source for fingerlings of mirror carp (Cyprinus carpio). Israeli Journal of Aquaculture - Bamidgeh 62: 272-280.

Byrne, O.M., Hardie, D.C., Khan, T.N., Speijers, J., \& Yan, G. (2008). Genetic analysis of pod and seed resistance to pea weevil in a Pisum sativum $\times$ P. fulvum interspecific cross. Australian Journal of Agricultural Research 59: 854-862.

Chilvers, M.I., Horton, T.L., Peever, T.L., Kaiser, W.J., \& Muehlbauer, FJ. (2007). First report of Ascochyta blight of Pisum elatius (wild pea) in the Republic of Georgia caused by Ascochyta pisi. Plant Disease 91: 326-326.

Clement, S.L., Hardie, D.C., \& Elberson, L.R. (2002). Variation among accessions of for resistance to pea weevil. Crop Science 42: 2167-2173.

Clement, S.L., McPhee, K.E., Elberson, L.R., \& Evans, M.A. (2009). Pea weevil, Bruchus pisorum L. (Coleoptera: Bruchidae), resistance in Pisum sativum $\times$ Pisum fulvum interspecific crosses. Plant Breeding 128: 478-485.

Coward, F., Shennan, S., Colledge, S., Conolly, J., \& Collard, M. (2008). The spread of Neolithic plant economies from the Near East to northwest Europe: a phylogenetic analysis. Journal of Archaeological Science 35(1): 42-56.

Ćupina, B., Krstić, Đ., Mihailović, V., Mikić, A., \& Vasiljević, S. (2007). Urban populations of vetches (Vicia spp.) have potential for forage yields. Bioversity International Newsletter for Europe 34: 12.

Ćupina, B., Zlatković, B., Smýkal, P., Mikić, A., Jajić, I., ZeremskiSkorić, T., \& Medović, A. (2011). In situ evaluation of a Pisum sativum subsp. elatius population from the valley of the river Pčinja in southeast Serbia. Pisum Genetics 43: 20-24.

Ćupina, B., Mikić, A., Zorić, L., Krstić, Đ., Antanasović, S., Zlatković, B., \& Erić, P. (2012). Ex situ evaluation of forage yield components and forage yields in wild populations of French vetch (Vicia serratifolia Jacq.) from Serbia. Grassland Science in Europe 17: 673-675.

de la Rosa, L., \& Jouve, N. (1992). Genetic variation for isozyme genes and proteins in Spanish primitive cultivars and wild subspecies of Lens. Euphytica 59: 181-187.

DeGregorio, R., Schonbeck, M.W., Levine, J., Iranzo-Berrocal, G., \& Hopkins, H. (1995). Bigflower vetch and rye vs. rye alone as a cover crop for no-till sweet corn. Journal of Sustainable Agriculture 5(4): 7-18.

di Vito, M., \& Greco, N. (1994). Control of food legume nematodes in the Mediterranean Basin. EPPO Bulletin 24: 489-494.

El-Bouhssini, M., Sarker, A., Erskine, W., \& Joubi, A. (2008), First sources of resistance to Sitona weevil (Sitona crinitus Herbst) in wild Lens species. Genetic Resources and Crop Evolution 55: 1-4.

Errico, A., Conicella, C., \& Venora, G. (1991). Karyotype studies on Pisum fulvum and Pisum sativum, using a chromosome image analysis system. Genome 34: 105-108.

Ferguson, M.E., \& Robertson, L.D. (1999). Morphological and phenological variation in the wild relatives of lentil. Genetic 
Resources and Crop Evolution 46: 3-12.

Fondevilla, S., Ávila, C.M., Cubero, J.I., \& Rubiales, D. (2005). Response to Mycosphaerella pinodes in a germplasm collection of Pisum spp. Plant Breeding 124: 313-315.

Fondevilla, S., Torres, A.M., Moreno, M.T., \& Rubiales, D. (2007a). Identification of a new gene for resistance to powdery mildew in Pisum fulvum, a wild relative of pea. Breeding Science 57: 181-184.

Fondevilla, S., Carver, T.L., Moreno, M.T., \& Rubiales, D. (2007b). Identification and characterization of sources of resistance to Erysiphe pisi Syd. in Pisum spp. Plant Breeding 126: 113-119.

Fondevilla, S., Cubero, J.I., \& Rubiales, D. (2011). Confirmation that the Er3 gene, conferring resistance to Erysiphe pisi in pea, is a different gene from $e r 1$ and $e r 2$ genes. Plant Breeding 130: 281-282.

Fratini, R., \& Ruiz, M.L. (2006). Interspecific hybridization in the genus Lens applying in vitro embryo rescue. Euphytica 150: 271-280.

Ganade, G., \& Brown, V.K. (1997). Effects of below-ground insects, mycorrhizal fungi and soil fertility on the establishment of Vicia in grassland communities. Oecologia 109: 374-381.

Golubev, A.A. (1990). Habitats, collection, cultivation and hybridization of Vavilovia formosa Fed. Bulletin of Applied Botany, of Genetics and Plant Breeding 135: 67-75.

Gupta, D., \& Sharma, S.K. (2006). Evaluation of wild Lens taxa for agro-morphological traits, fungal diseases and moisture stress in North Western Indian Hills. Genetic Resources and Crop Evolution 53: 1233-1241.

Hamdi, A., \& Erskine, W. (1996). Reaction of wild species of the genus Lens to drought. Euphytica 91: 173-179.

Hardie, D.C., \& Clement, S.L. (2001). Development of bioassays to evaluate wild pea germplasm for resistance to pea weevil (Coleoptera: Bruchidae). Crop Protection 20: 517-522.

Jaaska, V., \& Leht, M. (2007). Phylogenetic relationships between and within sections Hypechusa, Narbonensis and Peregrinae of genus Vicia (Fabaceae) based on evidence from isozymes and morphology. Central European Journal of Biology 2: 137155.

Jha, A.B., Warkentin, T.D., Gurusamy, V., Tar'an, B., \& Banniza, S. (2012). Identification of Mycosphaerella blight resistance in wild species for use in pea breeding. Crop Science 52: 2462 2468.

Johri, A.K., Singh, G., \& Sharma, D. (1992). Nutrient uptake by wheat and associated weeds as influenced by management practices. Tropical Agriculture 69: 391-393.

Jovanović, Ž., Stanisavljević, N., Nikolić, A., Medović, A., Mikić, A., Radović, S., \& Đorđević, V. (2011). Pisum \& Ervilia Tetovac - made in Early Iron Age Leskovac. Part two. Extraction of the ancient DNA from charred seeds from the site of Hissar in South Serbia. Ratarstvo i povrtarstvo 48: 227-232.

Kaiser, W.J., Muehlbauer, F.J., Hannan, R.M., \& Mihov, M. (1998). First report of natural infection of Pisum sativum subsp. elatius by Mycosphaerella pinodes in Bulgaria. Plant Disease 82: 830 .

Katayama, N., Suzuki, N. (2011). Anti-herbivory defense of two Vicia species with and without extrafloral nectaries. Plant Eco$\log 212: 743-752$

Kenicer, G., Smýkal, P., Vishnykova, M., \& Mikić, A. (2009). Vavilovia formosa, an intriguing Pisum relative. Grain Legumes 51:8.

Khan, B.A. (1994). Aflatoxin contamination of poultry feed and resulting disorders in chicken. PhD Dissertation, University of Karachi, Karachi.

Kislev, M.E., \& Bar-Yosef, O. (1988). The legumes: The earliest domesticated plants in the Near East? Current Anthropology 29: 175-179.

Kosterin, O.E., \& Bogdanova, V.S. (2008). Relationship of wild and cultivated forms of Pisum L. as inferred from an analysis of three markers, of the plastid, mitochondrial and nuclear genomes. Genetic Resources and Crop Evolution 55: 735-755.

Krstić, B., Boža, P., Mihailović, V., Mikić, A., \& Krstić, Đ. (2007). Variability of certain botanical and agronomical characteristics of wild vetch (Vicia) in flora of Vojvodina. Ratarstvo i povrtarstvo 44(I): 125-133.

Küster, H., Quandt, H.J., Broer, I., Perlick, A.M., \& Pühler, A. (1995). The promoter of the Vicia faba L. VfENOD-GRP3 gene encoding a glycine-rich early nodulin mediates a predominant gene expression in the interzone II-III region of transgenic Vicia hirsuta root nodules. Plant Molecular Biology 29: 759-772.

Ladizinsky, G., \& Muehlbauer, FJ. (1993). Wild lentils. Critical Reviews in Plant Sciences 12: 169-184.

Lev, E., Kislev, M.E., \& Bar-Yosef, O. (2005). Mousterian vegetal food in Kebara cave, Mt. Carmel. Journal of Archaeological Science 32: 475-484.

Lev-Yadun, S., \& Inbar, M. (2002). Defensive ant, aphid and caterpillar mimicry in plants? Biological Journal of the Linnean Society 77: 393-398.

Lie, T.A., Timmermans, P.C.J.M., Ladizinsky, G. (1982). Hostcontrolled nitrogen fixation in the legume-rhizobium symbiosis: incompatibility of Pisum sativum L. ecotypes elatius Bieb. and abyssinicum Braun with European Rhizobium leguminosarum strains. Israel Journal of Botany 31: 163-167.

Lifante, Z.D., Luque, T., Santa-Bárbara, C. (1992). Chromosome numbers of plants collected during Iter Mediterraneum II in Israel. Bocconea 3: 229-250.

Maxted, N. (1995). An Ecogeographical Study of Vicia Subgenus Vicia. Rome, International Plant Genetic Resources Institute.

Maxted, N., Ambrose, M. (2001). Peas (Pisum L.). In: Maxted N, Bennett SJ (Eds.), Plant Genetic Resources of Legumes in the Mediterranean, Kluwer, Dordrecht, the Netherlands, 181190

Maxted, N., Ford-Lloyd, B.V., Jury, S., Kell, S., Scholten, M. (2006). Towards a definition of a crop wild relative. Biodiversity \& Conservation 15: 2673-2685.

McPhee, K.E., Tullu, A., Kraft, J.M., Muehlbauer, F.J. (1999). Resistance to Fusarium wilt race 2 in the Pisum core collection. Journal of the American Society for Horticultural Science 124: 28-31.

Medović, A., Jovanović, Ž., Stanisavljević, N., Radović, S., Mikić, A., Đorđević, V., Ćupina, B. (2010). An archaeobotanical and molecular fairy tale about the early Iron Age Balkan princess and the charred pea. Pisum Genetics 42: 35-38.

Melamed, Y., Plitmann, U., Kislev, M.E. (2008). Vicia peregrina: an edible early Neolithic legume. Vegetation History and Archaeobotany 17: 29-34.

Mihailović, V., Mikić, A., Ćupina, B., Vasiljević, S., Krstić, Đ., Tomić, Z., Vasić, M. (2007). Genetic resources of annual forage legumes in the world and Serbia. Ratarstvo i povrtarstvo 44(I): $115-123$.

Mikić, A. (2012). Origin of the words denoting some of the most ancient Old World pulse crops and their diversity in modern European languages. PLoS ONE 7: e44512.

Mikić, A., Mihailović, V, Ćupina, B., Vasiljević, S., Krstić, Đ., Milić, D. (2008). Forage yields in urban populations of narrowleafed vetch (Vicia sativa subsp. nigra (L.) Ehrh.) from Serbia. Grassland Science in Europe 13: 284-286.

Mikić, A., Angelova, S., Burstin, J., Đurić, B., Ćupina, B., Lejeune, I., Sabeva, M., Vishnyakova, M., Duc, G. (2009a). The pea genetic resources of the Balkans, to represent the first cultivated peas of Europe. Grain Legumes 52: 16-17.

Mikić, A., Mihailović, V., Ćupina, B., Krstić, Đ., Hauptvogel, R., Drobná, J., Antalíková, G. (2009b). Forage yields in urban populations of large-flowered vetch (Vicia grandiflora Scop.) from Serbia. Grassland Science in Europe 14: 421-424.

Mikić, A., Mihailović, V., Hauptvogel, P., Ćupina, B., Petrović, M., Krstić, Đ., Jovičić, D., Milošević, B., Hauptvogel, R. (2009c). 
Wild populations of vetches ( Vicia) as forage and green manure crops for temperate regions. Irish Journal of Agricultural and Food Research 48: 265.

Mikić, A., Smýkal, P., Kenicer, G., Vishnyakova, M., Akopian, J., Sarukhanyan, N., Gabrielyan, I., Vanyan, A., Toker, C., Ćupina, B., Ambrose, M., Mihailović, V., Ellis, N. (2009d). A revival of the research on beautiful vavilovia (Vavilovia formosa syn. Pisum formosum). Pisum Genetics 41: 34-39.

Mikić, A., Smykal, P., Kenicer, G., Sarukhanyan, N., Akopian, J., Gabrielyan, I., Vanyan, A., Sinjushin, A., Demidenko, N., Cupina, B., Mihailović, V., Vishnyakova, M., Ambrose, M. (2010). Achievements in research on vavilovia (Vavilovia formosa (Stev.) Fed.), a legume crop wild relative. Ratarstvo i povrtarstvo 47: 387-394.

Mikić, A., Sarukhanyan, N., Akopian, J., Vanyan, A., Gabrielyan, I., Torchyan, V., Sarukhanyan, S., Cupina, B., Zeremski-Škorić, T., Krstić, Đ., Smýkal, P., Kenicer, G., Ambrose, M. (2011). Conservation strategies of Vavilovia formosa (syn. Pisum formosum), a high-mountainous pea relative in Armenia. Grassland Science in Europe 16: 371-373.

Mikić, A., Ćupina, B., Mihailović, V., Krstić, Đ., Đorđević, V., Perić, V., Srebrić, M., Antanasović, S., Marjanović-Jeromela, A., \& Kobiljski, B. (2012a). Forage legume intercropping in temperate regions: Models and ideotypes. In: Lichtfouse E. (Ed.), Sustainable Agriculture Reviews 11, Dordrecht, Springer Science+Business Media, 161-182.

Mikić, A., Mihailović, V., Ćupina, B., Antanasović, S., Krstić, Đ., Milošević, B., \& Katanski, S. (2012b). Ex situ evaluation of forage yield components and forage yields in wild populations of yellow vetchling (Lathyrus aphaca L.) from Serbia. Grassland Science in Europe 17:695-697.

Mikić, A., Mihailović, V., Ćupina, B., Antanasović, S., Krstić, Đ., Zlatković, B., Đorđević, V., Zorić, L., Taški-Ajduković, K., \& Nagl, N. (2013a). Ex situ evaluation of cultivation potential in wild populations of large-flowered vetch (Vicia grandiflora). Euphytica DOI 10.1007/s10681-013-0872-8

Mikić, A., Mihailović, V., Dimitrijević, V., Petrović, S., Ćupina, B., Đorđević, V., Kosev, V., Milošević, B., Jovanović, Ž., \& Milovac, Ž. (2013b). Evaluation of seed yield and seed yield components in red-yellow (Pisum fulvum) and Ethiopian (Pisum abyssinicum) peas. Genetic Resources and Crop Evolution 60: 629-638.

Mikić, A., Smýkal, P., Kenicer, G., Vishnyakova, M., Sarukhanyan, N., Akopian, J., Vanyan, A., Gabrielyan, I., Smýkalová, I., Sherbakova, E., Zorić, L., Atlagić, J., Zeremski-Škorić, T., Ćupina, B., Krstić, Đ., Jajić, I., Antanasović, S., Đorđević, V., Mihailović, V., Ivanov, A., Ochatt, S., \& Ambrose, M. (2013c). The bicentenary of the research on 'beautiful' vavilovia (Vavilovia formosa), a legume crop wild relative with taxonomic and agronomic potential. Botanical Journal of the Linnean Society http://dx.doi.org/10.1111/boj.12060.

Ochatt, S.J., Benabdelmouna, A., Marget, P., Aubert, G., Moussy, F., Pontécaille, C., \& Jacas, L. (2004). Overcoming hybridization barriers between pea and some of its wild relatives. Eupbytica 137: 353-359.

Ohta, N., Mori, N., Kuwahara, Y., \& Nishida, R. (2006). A hemiterpene glucoside as a probing deterrent of the bean aphid, $M e-$ goura crassicauda, from a non-host vetch, Vicia hirsuta. Phytochemistry 67: 584-588.

Pastor-Cavada, E., Juan, R., Pastor, J.E., Alaiz, M., \& Vioque, J. (2009a). Antioxidant activity of seed polyphenols in fifteen wild Lathyrus species from South Spain. LWT - Food Science and Technology 42: 705-709.

Pastor-Cavada, E., Juan, R., Pastor, J.E., Alaiz, M., \& Vioque, J. (2009b). Chemical composition and nutritional characteristics of the seed oil of wild Lathyrus, Lens and Pisum species from southern Spain. Journal of the American Oil Chemists' Society 86: 329-335.

Pérez-de-Luque, A., Jorrín, J., Cubero, J.I., \& Rubiales, D. (2005).
Orobanche crenata resistance and avoidance in pea (Pisum spp.) operate at different developmental stages of the parasite. Weed Research 45: 379-387.

Perrino, P., Maruca, G., Lester, R.N., Linsalata, V., Lattanzio, V., \& Hanelt, P. (1991). Chemotaxonomic relationship among species of Vicia section Faba. Feddes Repertorium 102: 319334.

Prasad, L.K., \& West, N.E. (1996). Potential of medics, trifoliums, melilotus as companion forage crop with oat. In: Proceedings of the Fifth International Rangeland Congress, Salt Lake City, Utah, USA, 23-28 July 1995, 450-451.

Roberts, H.A., \& Boddrell, J.E. (1985). Seed survival and seasonal pattern of seedling emergence in some Leguminosae. Annals of Applied Biology 106: 125-132.

Rubiales, D., Sillero, J.C., \& Emeran, A.A. (2013). Response of vetches (Vicia spp.) to specialized forms of Uromyces vicia-fabae and to Uromyces pisi. Crop Protection 46: 38-43.

Rydberg, N.T., \& Milberg, P. (2000). A survey of weeds in organic farming in Sweden. Biological Agriculture \& Horticulture 18: 175-185.

Şahin, A., \& Babaç, M.T. (1990). Cytotaxonomic studies of some Vicia L. species in eastern and south-eastern Anatolia. I. Doğa, Türk Botanik Dergesi 14: 124-138.

Sahin, A., Genç, H., \& Bagci, E. (2000). Cytotaxonomic investigations on some Lathyrus L. species growing in eastern Mediterrenean and southern Aegean regions - II. Acta Botanica Gallica 147: 243-256.

Sharma, B.K., \& Lavania, G.S. (1978). Interference between pure populations of two forage legumes, Vicia hirsuta Gray and $V$. sativa L.[India]. Indian Journal of Ecology 5: 55-60.

Sillero, J.C., Cubero, J.I., Fernández-Aparicio, M., \& Rubiales, D. (2005a). Search for resistance to crenate broomrape (Orobanche crenata) in Lathyrus. Lathyrus Lathyrism Newsletter 4 : 7-9.

Sillero, J.C., Moreno, M.T., \& Rubiales, D. (2005b). Sources of resistance to crenate broomrape among species of Vicia. Plant Disease 89: 23-27.

Singh, B.N., \& Singh, L.B. (1939). Relative absorption of nutrients by weeds of arable land. Soil Science 47: 227-236.

Sinjushin, A.A., \& Belyakova, S.A. (2010). On intraspecific variation of Vavilovia formosa (Stev.) Fed. (= Pisum formosum (Stev.) Alef.: Fabeae). Pisum Genetics 42: 31-34.

Sliesaravičius, A., Maršalkienè, N., Dastikaitė, A., Lübberstedt, T., Studer, B., \& Graugaard, S. (2007). Investigation of some wild annual vetch (Vicia L). In: Proceedings of the XXVIIth EUCARPIA Symposium on improvement of fodder crops and amenity grasses, Copenhagen, Denmark, 19-23 August 2007, 213-216.

Smykal, P., Kenicer, G., Flavell, A., Kosterin, O., Redden, R., Ford, R., Coyne, C., Maxted, N., Ambrose, M., \& Ellis, T.H.N. (2010). Phylogeny, phylogeography and genetic diversity of Pisum genus. Plant Genetic Resources: Characterization and Utilization 9: 4-18.

Smýkal, P., Aubert, G., Burstin, J., Coyne, C.J., Ellis, T.H.N., Flavell, A.J., Ford, R., Hýbl, M., Macas, J., Neumann, P., McPhee, K.E., Redden, R.J., Rubiales, D., Weller, J.L., \& Warkentin, T.D. (2012). Pea (Pisum sativum L.) in the genomic era. Agronomy 2: 74-115.

Sonnante, G., De Paolis, A., \& Pignone, D. (2005). Bowman-Birk inhibitors in Lens: identification and characterization of two paralogous gene classes in cultivated lentil and wild relatives. Theoretical and Applied Genetics 110: 596-604.

Sonnante, G., Hammer, K., \& Pignone, D. (2009). From the cradle of agriculture a handful of lentils: history of domestication. Rendiconti Lincei 20: 21-37.

Tanno, K., \& Willcox, G. (2006). The origins of cultivation of Cicer arietinum L. and Vicia faba L.: Early finds from Tell elKerkh, north-west Syria, late 10th millennium B.P. Vegetation 
History and Archaeobotany 15: 197-204.

Terziiski, D., \& Dimitrov, B. (1983). Karyotype analysis in Vicia hirsuta (L.) SF Gray and Vicia meyeri Boiss. Caryologia 36: 5560.

Tiwari, S. (2008). Plants: A rich source of herbal medicine. Journal of Natural Products 1: 27-35.

Tomić, Z., Đukić, D., Katić, S., Vasiljević, S., Mikić, A., Milić, D., Lugić, Z., Radović, J., Sokolović, D., \& Stanisavljević, R. (2005a). Genetic resources and improvement of forage plants in Serbia and Montenegro. Acta Agriculturae Serbica 19: 3-16.

Tomić, Z., Mrfat-Vukelić, S., Žujović, M., Nešić, Z., \& Krnjaja, V. (2005b). Useful species as quality factors of meadow vegetation on Stara Planina Mountain. Grassland Science in Europe 10: 240-243.

Tullu, A., Buchwaldt, L., Lulsdorf, M., Banniza, S., Barlow, B., Slinkard, A.E., Sarker, A., Tar'an, B., Warkentin, T., \& Vandenberg, A. (2006). Sources of resistance to anthracnose (Colletotrichum truncatum) in wild Lens species. Genetic Resources and Crop Evolution 53: 111-119.

Van Assche, J.A., \& Vandelook, F.E. (2010). Combinational dormancy in winter annual Fabaceae. Seed Science Research 20: 237.

Van de Ven, W.T.G., Duncan, N., Ramsay, G., Phillips, M., PoweIl, W., \& Waugh, R. (1993). Taxonomic relationships between V. faba and its relatives based on nuclear and mitochondrial RFLPs and PCR analysis. Theoretical and Applied Genetics 86:
$71-80$

Vaquer, J., Geddes, D., Barbaza, M., \& Erroux, J. (1986). Mesolithic plant exploitation at the Balma Abeurador (France). Oxford Journal of Archaeology 5: 1-18.

Weeden, N.F., Brauner, S., \& Przyborowski, J.A. (2002). Genetic analysis of pod dehiscence in pea (Pisum sativum L.). Cellular and Molecular Biology Letters 7(2B): 657-663.

Werker, E., Marbach, I., \& Mayer, A.M. (1979). Relation between the anatomy of the testa, water permeability and the presence of phenolics in the genus Pisum. Annals of Botany 43: 765 771.

Willcox, G., Fornite, S., \& Herveux, L. (2008). Early Holocene cultivation before domestication in northern Syria. Vegetation History and Archaeobotany 17:313-325.

Wroth, J.M. (1998). Possible role for wild genotypes of Pisum spp. to enhance ascochyta blight resistance in pea. Animal Production Science 38: 469-479.

Yan'kov, I., \& Golubev, A.A. (1999). About the taxonomical status of vavilovia formosa based on the results of crossibility and susceptibility to specialized pathogens. CD XVI International Botanical Congress, St. Louis, USA, 5655

Zlatković, B., Mikić, A., \& Smýkal, P. (2010). Distribution and new records of Pisum sativum subsp. elatius in Serbia. Pisum Genetics 42: 15-17.

Zohary, D., \& Hopf, M. (2000). Domestication of plants in the Old World: the origin and spread of cultivated plants in West Asia, Europe and the Nile Valley. Oxford, Oxford University Press.

\title{
Genetički resursi jednogodišnjih mahunarki umerenih klimata: I. Divlji srodnici gajenih vrsta
}

\author{
Aleksandar Mikić • Vojislav Mihailović
}

Sažetak: Ovaj pregledni rad teži da prikaže divlje srodnike jednogodišnjih mahunarki i pokuša da odgovori kako i čime, nezvanični rečeno, ovi taksoni imaju da ponude gajenim vrstama, u smislu prinosa, kvaliteta, otpornosti na stres i ostale agronomski značajne osobine. Oni predstavljaju široki izvor gena za poželjna svojstva, posebno za ona u vezi s abiotičkim i biotičkim stresom, koja mogu biti unesena u postojeće sorte, prevazilazeći moguće fiziološke ili genetičke prepreke. Široka međusobna varijabilnost najvažnije osobine može biti izuzetno korisna za postojeće sorte, usled brojnih „uskih grla“ i uzane genetičke osnove. Posmatrajući sa šireg stanovišta, divlji srodnici jednogodišnjih mahunarki umerenih klimata predstavljaju ne samo nacionalno ili regionalno blago, već i sredstvo za unapređenje savremene poljoprivrede na dobrobit čitavog čovečanstva.

Ključne reči: divlji srodnici, Fabaceae, genetički resursi, jednogodišnje mahunarke umerenih klimata, oplemenjivanje, unapređenje gajenih biljaka 